\title{
Financial Statement Complexity and Bank Lending*
}

\author{
Indraneel Chakraborty \\ Miguel Minutti-Meza
}

\author{
Andrew J. Leone \\ Matthew A. Phillips
}

October 23, 2018

\begin{abstract}
Recent studies and anecdotal evidence suggest that investors struggle to process complex financial reports. Existing theory and evidence demonstrate that banks not only have unique advantages in acquiring information, relative to equity and public debt investors, but also can impose contractual terms to mitigate information frictions. We investigate whether financial statement complexity is associated with firms' reliance on bank financing and with the terms of bank loans (i.e., the amount and rate of the loan, along with covenants and collateral). We focus on two dimensions of complexity that capture the volume and presentation of financial information: 10-K length and readability. We find that complexity is positively associated both with firms' reliance on bank financing and with banks increasing their level of screening, rationing their credit supply, and imposing tighter covenants. Our results suggest that banks continue to play their role as informed capital providers in a changing economy, characterized by growing financial statement complexity and innovations in banks' business models.
\end{abstract}

Keywords: complexity, financial statements, bank lending, debt contracting.

JEL codes: M41, G14, G21, G32, D82.

*We thank Sam Bonsall, Zahn Bozanic, John Donovan, Andrew McMartin, Brian Miller, Dushyant Vyas, Diana Weng (discussant) and seminar participants at the University of Miami, Carlos III of Madrid and 2018 Florida Accounting Symposium for helpful comments. We also thank Tim Loughran and Bill McDonald for the annual report word count data and Peter Demerjian for the probability of covenant violation data. Chakraborty, Minutti-Meza and Phillips are with the University of Miami. Leone is with Northwestern University. Indraneel Chakraborty: i.chakraborty@miami.edu. Andrew Leone: andrew.leone@kellogg.northwestern.edu. Miguel Minutti-Meza: mminutti@bus.miami.edu. Matthew A. Phillips: mphillips@bus.miami.edu. Andrew Leone is the corresponding author. 


\section{Introduction}

"This report, by its very length, defends itself against the risk of being read."

- Winston Churchill

Financial statements enable capital providers to screen investment opportunities and to monitor firms' use of capital. However, over the last two decades financial statements have become longer and less readable. A number of studies show that investors struggle to process complex financial reports. ${ }^{1}$ Even sophisticated financial statement users, such as analysts and credit rating agencies, are impacted by complex reports (e.g., Lehavy et al., 2011; Bonsall and Miller, 2017). Recent evidence indicates that firms take actions to mitigate the costly consequences of financial statement complexity, including issuing voluntary disclosure and increasing expertise within boards of directors (Guay et al., 2016; Chychyla et al., 2018). In this study, we investigate whether banks play a role in reducing information frictions associated with financial statement complexity.

Existing theory and evidence suggest that banks have unique advantages in acquiring and processing information. This is because the lending process allows banks access to private information about borrowing firms (Sharpe, 1990; Rajan, 1992; Petersen and Rajan, 1994). Hence, as the financial statement complexity of a firm increases, ceteris paribus, bank financing can be more attractive compared to other sources of external financing. This paper empirically examines whether two factors - firms' reliance on bank financing and the terms of bank loans - are related to financial statement complexity. ${ }^{2}$ We argue that, on the margin, firms prefer to obtain more financing from sources that are better at acquiring and processing complex information. Banks screen (Stiglitz and Weiss, 1981; Ramakrishnan and Thakor, 1984; Fama, 1985; Diamond, 1991) and monitor their clients by giving incentives through covenants and the threat of termination (Stiglitz and Weiss, 1983; Diamond, 1984; Rajan and Winton, 1995). Thus, banks can provide complex firms with informed financing that is cheaper compared to costly arm's-length financing (James, 1987; Rajan, 1992). These arguments motivate our first testable hypothesis: Firms with comparatively high financial statement complexity have a higher proportion of bank debt.

\footnotetext{
${ }^{1}$ See, for example, Li (2008); You and Zhang (2009); Miller (2010); Lee (2012); Lawrence (2013); Loughran and McDonald (2014); Hwang and Kim (2017).

${ }^{2}$ Practitioners and regulators are also concerned with increasingly complex financial reports. For instance, as part of a mandate from the JOBS Act, the U.S. Securities and Exchange Commission (SEC) performed a study on the disclosure requirements of regulation S-K and later invited input to better evaluate disclosure requirements (Securities and Exchange Commission, 2013).
} 
Financial statement complexity can arise due to compliance with financial reporting standards or managerial discretion. In the first case, complex financial reporting is a consequence of a firm's business operating environment and the applicable financial reporting standards (Guay et al., 2016; Dyer et al., 2017; Chychyla et al., 2018). A complex firm benefits by approaching banks for marginal financing because banks have expertise in allocating financing and have access to the borrowing firms' private information. In the second case, complex financial reporting can arise when managers wish to obfuscate and hide information from investors - for example, when the firm has performed poorly $(\mathrm{Li}, 2008)$. However, in this second case managers will not likely approach banks and subject their financial information to increased monitoring (Stiglitz and Weiss, 1983; Diamond, 1984; Rajan and Winton, 1995). Thus, our paper primarily focuses on a firm's business environment and the applicable financial reporting standards as sources of financial statement complexity.

The role of banks in the economy has changed in recent years, potentially influencing the association between financial statement complexity and bank financing. Due to the development of structured financial products such as collateralized loan obligations (CLOs), banks increasingly originate loans and sell them to other investors. Loan securitization reduces the incentives of banks to screen borrowers and monitor loans. ${ }^{3}$ Because banks face decreasing incentives to process borrowers' information, banks may no longer represent an advantageous source of financing for complex firms. Thus, our first research question helps us to examine whether banks still serve their traditional role of bridging the information gap between firms and capital markets.

We focus on two dimensions of complexity that capture the volume and presentation of financial information motivated by prior literature: 10-K length and readability. We measure length using the natural logarithm of the number of words in a firm's 10-K filing, which captures the time and effort that users need to process financial reports (Guay et al., 2016). We measure readability using the Bog Index, which captures processing costs linked to the type of language used in financial reports (Bonsall et al., 2017; Bonsall and Miller, 2017). Although we employ these measures as observable proxies for firm complexity, we do not suggest that banks are simple consumers of financial statements. ${ }^{4}$

\footnotetext{
${ }^{3}$ Existing literature suggests that lenders contract differently when loans will be securitized. For example, Bozanic et al. (2018) find that CDO loan originations have more standardized covenant definitions as opposed to borrower-specific covenants.

${ }^{4}$ This is because banks have access to private information about firms. Hence, banks are not solely reliant upon information provided within financial statements.
} 
Our main measure of firm reliance on bank financing is the total amount of a firm's bank debt, scaled by its total assets. ${ }^{5}$ We document that financial statement complexity is positively associated with firms' reliance on bank financing, both cross-sectionally and within firms. Specifically, we estimate that for one standard deviation increase in financial statement length, firms obtain 0.84 of a percentage point (pp) more bank debt as a fraction of total assets. One standard deviation of financial statement length is approximately 36,700 words, which is approximately 46 pages. Similarly, for one standard deviation decrease in readability, firms obtain 0.76 of a pp more bank debt. These findings are consistent with firms using banks as a financing alternative to reduce information frictions linked to financial statement complexity. Our identification strategy relies on variation in complexity across firms and over time. We control for a number of traditional firm-level proxies for business complexity, such as size and number of segments. We also control for variation at the industry-year level to mitigate concerns that our results are driven by common shocks to the business environment and accounting standards.

Next, we investigate how banks address complex information. Arguably, despite banks' advantages in dealing with information asymmetry, banks must exert incremental effort to screen and monitor complex borrowers. If financial statement complexity captures information processing costs for lenders, then we expect contractual differences for complex borrowers along two dimensions: (1) terms that are determined ex-ante (e.g., loan amounts and rates); and (2) terms that give banks control rights in ex-post renegotiations (e.g., covenants and collateral). Beyond price-protection, control rights are important because banks write incomplete contracts with an expectation of future renegotiations (see, among others, Aghion and Bolton, 1992; Dichev and Skinner, 2002; Chava and Roberts, 2008; Christensen et al., 2016). These arguments motivate our second hypothesis: Firms with comparatively high financial statement complexity (a) pay higher interest rates for bank debt, (b) obtain lower loan amounts, (c) face tighter covenants, and (d) must meet higher collateral requirements.

We document that financial statement complexity is linked to the following actions taken by banks: increasing their level of screening, rationing their credit supply, imposing tighter covenants and demanding

\footnotetext{
${ }^{5}$ This paper focuses on the choice between bank debt and public debt for firms with potential access to both markets. Arguably, the marginal source of financing for new projects is debt financing, which is typically cheaper than equity financing (e.g. Modigliani and Miller, 1963; Myers and Majluf, 1984; Shyam-Sunder and Myers, 1999; DeAngelo et al., 2011, among others). In other words, conditional on a given leverage ratio, we examine how a firm chooses the source of debt financing. As discussed in later sections, our results are robust to alternative definitions of firm reliance on bank financing.
} 
collateral. For instance, we find that with one standard deviation increase in complexity, firms obtain approximately three to four percent smaller loans based on the measure of complexity. At the same time, we find that loan pricing, the number and strictness of covenants, and collateral requirements all increase with financial statement complexity. These results suggest that, in equilibrium, banks use a variety of contractual levers when negotiating with firms. However, our findings do not imply that complex firms face all restrictions mentioned above. Importantly, our results are not in conflict. Even though within bank loans complex firms pay more due to relatively higher information processing costs (hypothesis two), between bank loans and other sources of financing, bank loans are cheaper (hypothesis one).

We conduct six additional analyses that extend and support our main findings. First, we examine the interaction between growing financial statement complexity over time and firms' reliance on bank debt. Generally, there is a trend upward in firms' reliance on bank debt during the period 2004-2015. However, complex firms increase their levels of bank debt at a comparatively faster rate (see Figure 3 for an illustration of this trend). In other words, bank lending remains an important source of financing in a changing economy (Boot and Thakor, 2000; Gande and Saunders, 2012).

Second, we examine the link between complexity and relationship lending. Beyond approaching a bank for additional financing, a complex firm can also cultivate strong relationships with its existing lenders to reduce the costs of complexity. We document that firms with comparatively higher statement complexity have stronger relationships with their lead-banks, in terms of the number and amount of loans with the same lead arranger. ${ }^{6}$

Third, we seek to identify the sources of complexity that lead firms to seek bank financing. We distinguish between complexity arising from (a) intricacy of the applicable accounting standards, captured by the length of the accounting footnotes; and (b) the firms' business operations and discussions of performance, captured by the length of the rest of the $10-\mathrm{K} .{ }^{7}$ Our evidence suggests that our inferences are attributable to the complexity of disclosures about firms' business operations.

Fourth, we examine the association between complexity and public debt. If complex firms' reliance on

\footnotetext{
${ }^{6}$ These results are consistent with empirical research in financial intermediation that investigates how firms and banks address information asymmetry. For example, Petersen and Rajan (1994) show that firms with close ties to banks have better access to bank debt financing than firms without the same degree of banking ties.

${ }^{7}$ For instance, accounting standards for pensions, stock compensation, and derivatives require firms to produce lengthy accounting footnotes. Our measure is related to the proxies in Peterson (2012) and Filzen and Peterson (2015). The business operations and performance disclosures are intended to capture compliance with SEC reporting standards.
} 
bank financing is linked to banks' screening and monitoring abilities, we would not expect a comparable relation between complexity and reliance on non-bank debt (e.g. public debt). Public debt investors are at arm's length and typically dispersed, and they do not have the same ability to acquire and process complex information that banks do. We do not find compelling evidence that financial statement complexity is related to non-bank debt financing. ${ }^{8}$ Thus, it is not the case that higher complexity is associated with higher debt financing in general. ${ }^{9}$ This distinguishes our work from that of Bonsall and Miller (2017), who find that complexity increases the cost of public debt and disagreement among credit rating agencies.

Further, we compare the estimated sensitivities of bank and bond financing to complexity. Bonsall and Miller (2017) show that one standard deviation increase in complexity (Bog Index) increases the cost of public debt financing by approximately $14 \mathrm{bps} .{ }^{10}$ We estimate an increase of approximately 4 bps for one standard deviation increase in Bog Index. This comparison suggests that bank loans are a relatively cheaper source of financing for complex firms. Thus, in equilibrium, complex firms should rely more on bank debt.

Fifth, we test whether our results are robust to alternative measurements of bank reliance and future time horizons. Our inferences are robust to using three alternative specifications of bank reliance: scaling bank debt by total debt, using the natural logarithm of bank debt, and scaling bank debt by total assets while excluding firms without any debt. Next, looking at future time horizons we seek to address reversecausality issues, where the properties of disclosure are driven by bank borrowings. We examine future bank reliance over one to five year periods. We find that the association between future bank reliance and complexity supports our main analyses. Moreover, the magnitude of this association is somewhat stronger when examining longer time periods, suggesting that complexity has a long term impact on bank reliance. Overall, our inferences are unlikely to be driven by the choice of scalar or reverse-causality.

Sixth, we use entropy balancing to mitigate the effect of differences in firm characteristics between firms

\footnotetext{
${ }^{8}$ In one specification, we find readability is related to non-bank financing. However, the relation does not remain when we use alternative model designs.

${ }^{9}$ Pecking order theory suggests that debt financing is cheaper than equity financing (Myers and Majluf, 1984; Shyam-Sunder and Myers, 1999). However, pecking order theory does not imply that bank debt financing is cheaper than public debt market financing. Sharpe (1990) and Rajan (1992) suggest that bank financing may be more expensive because banks attempt to extract surplus from their relationships. Empirically, Bharath et al. (2011) find that as firms become larger, they graduate to public debt market financing and bank relationships on average become transactional. Thus, our finding that firms with complex financial statements rely on bank financing is not a result that can be explained by pecking order theory.

${ }^{10}$ Page 610 of Bonsall and Miller (2017) discusses that a 25 percentage points decrease in Bog Index from the median value decreases the interest rate by 10.2 bps $(=\$ 440,000 / \$ 430,000,000 \times 100)$. Assuming a normal distribution with 34 percent as one standard deviation implies 14 bps $(=10.2 \times 34 / 25)$.
} 
with high and low levels of complexity. Our results are robust to using entropy balancing, although we find muted relations between readability and loan pricing as well as readability and collateral requirements.

Our study complements prior work that considers how accounting quality affects firms' choice of private versus public debt. Bharath et al. (2008) find that firms with poorer accounting quality rely more on bank debt. They point out that this is because banks are better able to handle information risk of such firms. Our paper argues that banks are also able to process complex information about borrowing firms more effectively. Thus, banks incur relatively lower information processing costs when conducting due diligence on such firms. Our inferences on complexity are incremental to accounting quality in our analyses.

In addition, our study extends three research streams. Its first and primary connection is to studies examining the costly consequences of financial statement complexity (Hirshleifer and Teoh, 2003; Miller, 2010; Cohen and Lou, 2012; Bonsall and Miller, 2017; Hwang and Kim, 2017). We focus on answering the question: What can firms do to address the costs of growing financial statement complexity? Diamond (1985) points out that firms can release information voluntarily to improve shareholder welfare and Guay et al. (2016) show that complex firms can provide incremental voluntary disclosure. Similarly, Chychyla et al. (2018) finds evidence that complex firms can invest in larger boards with more accounting expertise. Our findings also contribute to the debate involving researchers, practitioners, and policymakers about the trade-offs involved in increasing financial statement complexity (Dyer et al., 2017).

The second research stream continued in our study consists of literature that has demonstrated the unique role of banks the areas of information acquisition, borrower screening, and loan monitoring (Stiglitz and Weiss, 1981, 1983; Ramakrishnan and Thakor, 1984; Diamond, 1984; Fama, 1985; James, 1987; Diamond, 1991; Rajan, 1992; Rajan and Winton, 1995). Recent work has investigated the changing role of banks in a changing economy (Hellmann et al., 2000; Keys et al., 2010; Purnanandam, 2011; Benmelech et al., 2012). A number of studies have also investigated the choice between bank and public debt, along with equity (Denis and Mihov, 2003; Rauh and Sufi, 2010; Colla et al., 2013; Bharath and Hertzel, 2018). ${ }^{11}$ After considering several drivers proposed by the literature on debt choices and the role of banks, complexity is an incremental factor associated with the levels of private debt. Our results suggest that banks continue to play the role of informed capital providers in a changing economy, characterized by growing financial statement

\footnotetext{
${ }^{11}$ This adds to the seminal work that has considered the firm-level decision of leverage (seminal work includes Modigliani and Miller, 1963; Myers, 1977; Myers and Majluf, 1984, among others).
} 
complexity and business model innovations in the banking industry.

The third research stream extended in this paper is work that addresses the need for suitable empirical constructs to capture business complexity. Our results indicate that $10-\mathrm{K}$ length and readability measures capture variation in complexity linked to firms' business operations and performance. Notably, we show that variation in business complexity is not subsumed by traditional proxies used in debt and banking research, primarily firm size and number of segments.

The rest of the paper is organized as follows: Section 2 develops the testable hypotheses. Section 3 details the research design, and Section 4 provides data description. Section 5 presents a discussion of the results. Section 6 lays out the additional analyses performed and Section 7 gives the concluding remarks.

\section{Background and hypothesis development}

A growing literature demonstrates that financial statement complexity increases information processing costs for investors (Li, 2008; You and Zhang, 2009; Lehavy et al., 2011; Lee, 2012; Lawrence, 2013; Loughran and McDonald, 2014; Dyer et al., 2017; Miller, 2010; Bushee et al., 2018). Complex financial statements require more effort to process and therefore lead to delayed investor response and lower stock price efficiency. Research establishing this insight includes Hirshleifer and Teoh (2003), Corwin and Coughenour (2008), Miller (2010), Cohen and Lou (2012), Lawrence (2013), and Loughran and McDonald (2014), among others. Hirshleifer and Teoh (2003) show that investors' information processing costs can influence differences in their responses to complex accounting information. Cohen and Lou (2012) show that information regarding firms with a greater number of segments takes longer to be impounded in stock prices. Thus, information is more difficult to impound in prices when firms are more complex. Finally, Loughran and McDonald (2014) demonstrate that the file size of firms' 10-K filings is positively related to post-filing date abnormal return volatility.

Financial statement complexity may not affect all investors equally. However, as long as a fraction of the market is affected, firms with complex reporting likely face comparatively higher information asymmetry problems. Miller (2010) provides evidence that financial statement complexity is negatively related to trading volume by retail investors. In addition, Lawrence (2013) finds readable disclosures are a factor in firms' ability to attract retail investors. Furthermore, professional market participants face incremental processing 
costs in the presence of financial statement complexity. Lehavy et al. (2011) and Bozanic and Thevenot (2015) show that analyst forecasts are less accurate and exhibit higher dispersion when financial statements are more complex. Using the SEC's 1998 Plain English Mandate as an exogenous shock, Bonsall and Miller (2017) find that SEC filing readability is related to bond ratings, credit rating agency disagreement, and the cost of public debt.

Multiple factors contribute to a rising trend in financial statement complexity. First, the size and intricacy of the operations of global public companies, as well as advances in technology and financial markets, have affected the type and volume of transactions captured by financial reporting. Second, financial reporting standards and regulations have evolved to the point that firms must include a discussion of internal controls, risk factors, and complex accounting areas in their financial statements (Dyer et al., 2017). Finally, managerial discretion plays a role in describing the results of operations in the MD\&A section of the 10-K (Lo et al., 2017).

Given that information frictions and adverse selection are major concerns for capital markets (Akerlof, 1970; Rothschild and Stiglitz, 1976; Myers and Majluf, 1984), firms face the question of how to respond to increasing financial frictions due to reporting complexity. One possibility is for firms with high-quality investment projects to signal their type, resulting in a separating equilibrium based on project quality. For instance, firms may signal their type through capital structure (Leland and Pyle, 1977; Ross, 1977), voluntary disclosure (Diamond, 1985), or dividend policy (John and Williams, 1985). Thus, even in the presence of financial statement complexity, high-quality firms can obtain cost-effective financing through publicly disclosing their type. Indeed, Guay et al. (2016) find that firms with higher financial statement complexity are more likely to issue various types of voluntary disclosure. Moreover, complex firms may take additional costly actions to increase monitoring, such as appointing directors with accounting expertise (Chychyla et al., 2018).

A second possibility for firms that find it costly to credibly disclose their type is to obtain private financing. Banks are unique because they have expertise and access to private information that allows them to screen and monitor borrowers at a relatively low cost (Stiglitz and Weiss, 1981, 1983; Diamond, 1991). However, the banks' role in dealing with adverse selection may result in other costs for borrowers. Specifically, firms pay a premium for bank financing and also give away decision rights (Aghion and Bolton, 1992; 
Rajan, 1992; Chava and Roberts, 2008). Nevertheless, as long as the cost of signaling type through other mechanisms is higher, on the margin, bank financing can be appealing to complex firms. Thus, our first testable hypothesis is as follows:

Hypothesis 1. Firms with comparatively high financial statement complexity have a higher proportion of bank debt.

We next consider the mechanisms through which banks may address complexity. Banks make an effort to conduct due diligence so that they can screen prospective borrowing firms (Stiglitz and Weiss, 1981) and subsequently monitor borrowers actively (see, among others, Chava and Roberts, 2008; Nini et al., 2009, 2012). Over time, banks become repositories of borrowers' private information and are able to overcome information frictions faced by other arm's-length lenders (Petersen and Rajan, 1994). Banks also can negotiate ex ante debt structure and ex post monitoring mechanisms in response to information asymmetry. While banks are better suited to process complex information, they still incur information processing costs when conducting due-diligence on complex firms. To the extent that financial statement complexity captures these relative information processing costs for lenders, we would expect contractual differences along the aforementioned dimensions. As such, our next hypothesis explores the contractual design choices banks can use to mitigate information frictions arising from borrower's complexity.

First, banks can respond to complexity by rationing the credit supply and increasing loan rates (Petersen and Rajan, 1994). If financial statement complexity leads to information frictions between lenders and borrowers, then lenders can reduce loan amounts to limit their exposure or to compel refinancing. Refinancing allows the lender the option to continue, discontinue, or increase an investment in the future after acquiring more information about the borrower. In addition, lenders can price information risk through the interest rate charged on the loan.

Second, bank ex post monitoring can reduce some of the ex ante information processing costs of financial statement complexity. It would be very costly for banks to specify all relevant contingencies in a loan contract and thus it is theoretically optimal to include a mechanism for renegotiation (Hart and Moore, 1988; Aghion and Bolton, 1992). Empirically, extant literature demonstrates the importance of covenants and renegotiations in the optimal allocation of control rights (see, among others, Chava and Roberts, 2008; Nini et al., 2009, 2012). The usefulness of loan covenants in triggering renegotiations depends on the char- 
acteristics of the underlying financial reporting and on managerial incentives (Aghion and Bolton, 1992; Dewatripont and Tirole, 1994; Christensen and Nikolaev, 2012). Indeed, Garleanu and Zwiebel (2008) predict that creditors will demand greater control rights (through tighter covenants) upon facing firm complexity. Further, lenders can demand collateral to protect their investment and aid in renegotiations with complex firms.

We argue that financial statement complexity leads lenders to design contracts that protect them from information asymmetry problems with ex ante loan pricing and quantity and ex post monitoring power. Thus, our second testable hypothesis examines how loan contracts address information frictions in the presence of financial statement complexity:

Hypothesis 2. Firms with comparatively high financial statement complexity (a) pay higher interest rates for bank debt, (b) obtain lower loan amounts, (c) face tighter covenants, and (d) must meet higher collateral requirements.

We summarize $\mathrm{H} 2$ as follows. Part (a) tests whether financing costs increase due to high financial statement complexity, since loan pricing is an important channel through which complexity affects firms. Part (b) is an important complementary test because Petersen and Rajan (1994) show that the benefits of bank relationships work through quantities rather than prices. Part (c) is motivated by extant literature demonstrating that covenant tightness is a mechanism to ensure that banks retain bargaining power for later renegotiation (Gorton and Kahn, 2000; Dichev and Skinner, 2002). This becomes especially important in the case of firms with higher financial statement complexity as greater information asymmetry ex ante amplifies the importance of control rights ex post (Garleanu and Zwiebel, 2008). Finally, part (d) is motivated by extant literature showing that banks require higher collateral from riskier borrowers (Berger and Udell, 1990). We investigate whether financial statement complexity leads banks to shield themselves from lack of clarity about future prospects (Kim and Verrecchia, 1991).

\section{Research design}

Our first set of tests focuses on determining whether firms with comparatively high financial statement complexity have a higher proportion of bank debt. For a specific firm $i$ in period $t$, the specification that tests 
the first hypothesis is as follows:

$$
\text { Bank Reliance }_{i, t}=\alpha_{i}+\gamma_{t}+\beta_{1} \text { Complexity }_{i, t}+\beta_{2} \text { Firm Controls }_{i, t}+\varepsilon_{i, t} \text {. }
$$

We define bank reliance as total bank debt scaled by total assets. ${ }^{12}$ Next, we follow prior literature and use length and readability as our primary proxies for financial statement complexity. We measure length using the natural logarithm of the number of words in a firm's $10-\mathrm{K}$ filing. The length of a $10-\mathrm{K}$ filing (FS Length) captures the time and effort that users need to process financial reports (Guay et al., 2016). We measure readability using the Bog Index (Bog Index) as introduced in Bonsall et al. (2017). This index captures prose and stylistic properties of 10-K disclosure text that map closely to the SEC Plain English Handbook. These properties include the use of long sentences, the appearance of passive voice or weak verbs, and the frequency of overused words, complex words, or jargon. Further, this index uses a proprietary list of 200,000 terms to determine word complexity. The Bog Index captures processing costs linked to the type of language used in financial reports (Bonsall et al., 2017; Bonsall and Miller, 2017). ${ }^{13}$ The index is constructed so that higher values of Bog Index indicate lower readability. Lastly, Bonsall et al. (2017) show that the Bog Index is a more precise proxy for firms' financial statement complexity than two alternative measures: the Fog Index and the gross file size of the 10-K.

Our identification strategy relies on a combination of industry-year and firm fixed effects. The industryyear fixed effect essentially captures time-variant industry-related factors that influence complexity and financing. Next, firm fixed effects isolate firm-level time-invariant unobservable characteristics. We present our results with and without firm fixed effects. Hence, identification results from cross-sectional (within industry-year) and firm-level variation in financial statement complexity.

In our model, we include a comprehensive list of firm-level variables associated with financing choices

\footnotetext{
${ }^{12}$ The intuition behind why we scale bank debt by total assets, as opposed to by total debt, can be demonstrated with the following example. Suppose there are two firms, Firm A and Firm B. Firm A has $\$ 400 \mathrm{M}$ of total assets, $\$ 100 \mathrm{M}$ of bank debt and $\$ 100 \mathrm{M}$ of non-bank debt. Firm B has $\$ 400 \mathrm{M}$ of total assets, $\$ 10 \mathrm{M}$ of bank debt, and $\$ 5 \mathrm{M}$ of non-bank debt. In this case, scaling by total debt would suggest that Firm B, relative to Firm A, has a larger reliance on bank debt (67\% versus 50\%, respectively), despite financing a considerably lower amount of total assets with bank debt. We argue that the amount of assets financed by debt represents a better measure of bank reliance. In sensitivity tests, we use alternative definitions of bank reliance, including total bank debt scaled by total debt and the natural log of bank debt. Our inferences are robust to these alternative bank reliance measures.

${ }^{13}$ The SEC Plain English Handbook is a document released by the SEC in 1998 that promotes clear and and more informative disclosure. The handbook was intended to prompt issuers to reduce legal terminology and complex terms to help make disclosures more accessible to financial statement users.
} 
and financial statement complexity (Rajan and Zingales, 1995; Bharath et al., 2008; Guay et al., 2016). Specifically, we control for: probability of bankruptcy (Zscore), size (Firm Size), profitability (EBITDA), growth (Book to Market), asset tangibility (Tangibility), incidence of losses (Loss), special items (Special Items), cumulative stock returns (Returns), returns volatility (Return Volatility), business and geographic segments (Business Segments and Geographic Segments), presence of credit ratings (Unrated) and discretionary accruals (Discretionary Accruals). All variable definitions are available in Appendix A.

Our second set of tests examine whether firms with comparatively high financial statement complexity (a) pay higher interest rates for bank debt, (b) obtain lower loan amounts,(c) face tighter covenants, and (d) must meet higher collateral requirements. For a specific firm $i$ lending agreement in period $t$, the specification that tests the second hypothesis is as follows:

$$
\text { Contract terms }_{i, t}=\alpha_{i}+\gamma_{t}+\beta_{1} \text { Complexity }_{i, t-1}+\beta_{2} \text { Firm Controls }_{i, t-1}+\beta_{3}{\text { Loan } \text { Controls }_{i, t}+\varepsilon_{i, t}}_{\text {. }}
$$

Specifically, the contract terms we examine are loan amount, interest rate, number of covenants, covenant tightness, and whether the loan requires collateral. Loan amount and interest rate are terms set ex ante. Loan amount is the natural log of the loan principal and loan interest rate is measured as the basis points premium of the loan above LIBOR. The collateral requirements, number of covenants and covenant tightness allow creditors to maintain ex post bargaining power. Whether a loan is collateralized or not is measured by an indicator variable. The measure of covenant tightness is the probability of violating the loan covenant(s) as proposed in Demerjian and Owens (2016). The calculation of covenant violation probability is discussed in Demerjian and Owens (2016) and summarized in Appendix A.

In addition to the firm-level controls discussed above, we include indicator variables for the loan purpose, because firms may obtain new debt or re-finance existing debt for a variety of reasons that can drive contracting terms (for example, M\&A, working capital, or investment in new fixed assets). We also control for leverage (Book Leverage), whether the loan is a revolver (Revolver Dummy), whether the loan was originated by institutional investors (InstitutionalInvestor), length of the loan agreement (Maturity), whether the loan is a syndicated loan (SyndicatedLoan), frequency with which the borrower accesses the private lending market (LendingFrequency), whether the loan includes a performance pricing provision (PP Indicator), and ratio of balance sheet to income statement volatility (Volatility Ratio). We also include loan size 
(Loan Size) and whether the loan is secured (Secured) as control variables when they are not dependent variables. These controls are motivated by prior studies examining loan contracting outcomes (Costello and Wittenberg-Moerman, 2011; Demerjian, 2011).

\section{Sample and descriptive statistics}

\subsection{Bank reliance sample}

Our bank reliance sample is the intersection of COMPUSTAT, CRSP, S\&P Capital IQ Capital Structure, and the financial statement textual data made available by Loughran and McDonald (2014) and (Bonsall et al., 2017). We obtain financial and other data from COMPUSTAT and CRSP. S\&P Capital IQ Capital Structure has annual information related to the debt and equity capital structure of public companies. We use this data set to calculate the level of bank and non-bank debt reliance. Starting with companies available in S\&P Capital IQ, we retain any firm-year observation in which the amount of total debt per S\&P Capital IQ is within 10\% of COMPUSTAT to ensure debt composition data reliability (Colla et al., 2013). Importantly, we do not condition on the firm having a non-zero amount of bank debt. We remove observations in the financial services industry (Fama-French 29). Finally, we merge the resulting data set with the financial statement textual data provided by Tim Loughran (Loughran and McDonald, 2014) as well as the Bog Index data provided by Sam Bonsall (Bonsall et al., 2017). The resulting sample contains 21,775 firm-year observations for 4,217 distinct firms for the bank reliance tests. The sample period is 2001 through $2015 .^{14}$

\subsection{Debt contracting sample}

The primary data source for the debt contracting analysis is Thomson Reuters Dealscan. Dealscan is a database of private loan agreements, including many contract and lender characteristics. As noted in prior studies, Dealscan includes information at the package level and facility level. As part of a debt agreement, borrowers can request multiple credit facilities. For example, a borrower can request a term loan, where the principal and maturity are fixed, as well as a revolving credit agreement, where the borrower has the ability to draw credit on demand up to a certain amount with no fixed repayment date. Some variables correspond to the package level (e.g. covenant terms), while others relate to individual loans (e.g. interest rate). Following

\footnotetext{
${ }^{14}$ The Capital IQ capital structure data set detail for bank debt is poorly populated prior to 2001 .
} 
Ivashina (2009) among others, we use the largest loan within packages containing multiple loans to mitigate the influence of repetitive observations. Further, we filter loan records based on the presence of financial covenants because an absence of a financial covenant indicates that the loan record is likely incomplete (Christensen and Nikolaev, 2012).

We next match each loan observation to the probability of covenant violation data from Demerjian and Owens (2016). Then, we merge the Dealscan loan-package level observations to COMPUSTAT and CRSP using the link table provided by Michael Roberts (Chava and Roberts, 2008). For each loan, we use the most recent annual financial data. We include fiscal periods ending prior to 2015 to capture periods with the greatest coverage (and accordingly include all debt agreements during 2016). This results in a panel of loan observations with fiscal years from 1995-2015. Finally, we incorporate the financial statement complexity measures that correspond to the borrower's latest $10-\mathrm{K}$ filings prior to the debt issuance with data from Loughran and McDonald (2014) and Bonsall et al. (2017). The final sample consists of 8,722 loan observations for 2,850 distinct borrowers. The sample size is proportionally similar to recent studies that intersect Dealscan and EDGAR filing data (Nini et al., 2009; Baylis et al., 2017). All continuous variables in our samples are winsorized at the $1 \%$ and $99 \%$ levels. The summary of sample construction for both sets of analyses is presented in Table 1.

\subsection{Descriptive statistics}

Table 2 Panel A represents the descriptive statistics for the firm-year panel. The average word count in the 10-K (Raw Number of Words) for the firms in the sample is approximately 52 thousand words. The average 10-K length, natural logarithm of the number of words, is 10.7 (FS Length). The average 10-K readability, in terms of the Bog Index, is 85.2 (Bog Index). ${ }^{15}$ Firms borrow on average 12.8 percent of their assets from banks. In addition, firms borrow on average another 14.0 percent from non-bank sources (e.g. public bonds). Thus, bank debt is a slightly smaller fraction of debt relative to non-bank sources in our sample of firms.

The Altman Z-Score measure has a mean of 2.636. This measure is highly skewed, however, the median firm is in the mid-zone in terms of health and the 75th percentile firm is in the "safe" zone. Firm size is

\footnotetext{
${ }^{15}$ The untabulated correlation coefficient of the relation between FS Length and Bog Index is approximately 0.340.
} 
approximately 6 , suggesting that the average asset size of the firm in the sample is $\$ 450$ million. The book leverage is approximately 26.8 percent. The firms are typically profitable, with some unprofitable firms driving down the average profitability to $7.1 \%$. The book to market of the firms is approximately 60.1 percent.

Table 2 Panel B represents the descriptive statistics for the firm-loan observation panel. The average word count in the $10-\mathrm{K}$ for the contracting sample is approximately 38 thousand words. This word count is lower than the bank reliance sample due to the earlier time period of the contracting panel (beginning in 1995), consistent with complexity growing over time as illustrated in Figure 1. The contracting sample 10 -Ks are also more readable (83.4). The majority of bank loans in our sample require collateral (58 percent are secured). The average number of covenants, or covenant intensity, for each loan is about 2 . The average probability of covenant violation, or covenant tightness, is 36 percent. This number is skewed, as the median loan has an 10.6 percent probability of violation, suggesting that covenants are set tight for some loans (Dichev and Skinner, 2002).

Initially, we provide descriptive evidence that financial statement complexity is positively related to firms' bank financing. In Figures 2 - 4, we show a trend for adjusted financial statement length and readability because these proxies are significantly correlated to size, profitability, industry and year (Bonsall et al., 2017). We use the residuals from two models regressing each complexity proxy on size, profitability, and industry-year indicator variables. In Figure 2, we show an upward sloping relation between deciles of both adjusted complexity measures and bank debt reliance. In Figure 3, we show that the difference in bank financing between the highest and lowest deciles of statement complexity is increasing over time. In Figure 4, we also demonstrate that this trend generally holds even after considering total debt borrowings. This evidence is consistent with regulators' concerns that increasing financial statement complexity over time may influence the capital markets (Dyer et al., 2017). It also highlights the possibility that banks are getting better, relative to other capital providers, at handling increasing financial statement complexity.

\section{Results}

This section establishes the three main analyses of the paper: (i) firms rely on bank financing to mitigate information processing costs associated with complexity, (ii) banks ration credit supply to address imperfect 
information due to financial statement complexity, and (iii) banks impose tighter covenants and collateral requirements to maintain bargaining power in incomplete lending contracts.

\subsection{Bank debt reliance}

Table 3 shows the relation between bank debt and financial statement complexity. Columns (1) - (4) estimate the sensitivity of bank debt, as a fraction of firm assets, to financial statement complexity. We use two measures of complexity (length and readability) and employ two specifications. ${ }^{16}$ Columns (1) and (3) regress bank reliance on financial statement length, and columns (2) and (4) regress bank reliance on readability. The first specification controls for time-varying sector-specific economic conditions including industry-year fixed effects in columns (1) and (2), and the second specification controls for firm-specific differences including firm-level fixed effects in columns (3) and (4). In addition, both specifications include relevant variables that affect complexity and cost of financing.

The results in Table 3 support our first hypothesis. In columns (1) and (3), we find that financial statement length is positively and significantly associated with bank reliance $(p<.01)$. Cross-sectionally, we estimate that a one standard deviation (SD) increase in FS Length is associated with a 0.84 percentage points increase in bank debt. Assuming a page in a financial statement contains approximately 800 words, and given that one SD of financial statement length is 36,700 words, one SD increase in length is approximately 46 more pages of text. Similarly, a within-firm one SD increase in FS Length is associated with an approximately 0.42 percentage points increase in firm bank debt. In columns (2) and (4), we find that cross-sectionally the Bog Index is positively and significantly associated with bank reliance $(p<.01)$, but our within-firm estimate is not significant. ${ }^{17}$ We estimate cross-sectionally that a one SD increase in Bog Index corresponds to a 0.76 percentage points increase in bank debt. Overall, these estimates indicate that an economically significant portion of firm's capital structure decisions are related to the complexity of their accounting information. ${ }^{18}$ Further, the evidence is consistent with our prediction that firms mitigate information frictions associated

\footnotetext{
${ }^{16}$ In untabulated analyses, results remain when we use deciles instead of continuous measures of complexity.

${ }^{17}$ The direction of the coefficient on Firm Size is different on the levels and firm fixed effects models (Columns (1) - (2) and (3) - (4), respectively). This is primarily due to assets changing slowly for most firms over time, influencing the coefficient when including fixed effects. As a sensitivity analysis, we estimate the same regressions using the natural log of market value and the natural $\log$ of sales as alternative proxies for firm size and find similar inferences for our complexity variables.

${ }^{18}$ One concern related to these results is whether firms have more complex disclosure as a result of reliance of bank financing (i.e., reverse causality). To mitigate this issue, in untabulated analyses we run the cross-sectional bank reliance models with lagged complexity variables and covariates. Our results are robust to this approach, and remain significant at conventional levels.
} 
with complexity by obtaining financing from banks. ${ }^{19,20}$

\subsection{Loan price and quantity}

This section examines whether banks, in response to financial statement complexity, adjust two important dimensions of the credit supply: quantity and price of loans. Even though firms may choose banks over other sources of financing given their superior screening skills, it does not mean that banks are able to costlessly eliminate the information frictions derived from financial statement complexity. However, if banks were able to eliminate such frictions completely through screening and contracting, we should not expect an association between bank's credit supply and financial statement complexity. Thus, this section conducts a test on the residual frictions: given that banks reduce information asymmetry by screening borrowing firms, and then write contracts to reduce adverse selection, we ask if there is any residual response to financial statement complexity in the form of loan quantity and prices.

Table 4 reports the results of our tests of whether loan amounts and interest rate spread are related to financial statement length and readability. Our specification includes time-varying and static firm-year controls, as well as a number of loan-level characteristics likely to influence both a loan's structure and financial statement complexity (Costello and Wittenberg-Moerman, 2011; Guay et al., 2016). Further, we include industry-year and loan-purpose fixed effects to capture differences in industries, time, and financing purposes.

Columns (1) and (3) regress the natural log of loan size on FS Length and Bog Index. We find both complexity measures are significantly and negatively related to loan size $(p<.05)$. We estimate that one SD higher FS Length leads to 3.9 percent lower loan amounts, and one SD higher Bog Index leads to 3.5 percent lower loan amounts. This evidence is consistent with lenders rationing credit supply in response to financial statement complexity.

\footnotetext{
${ }^{19} \mathrm{We}$ acknowledge that winsorization is only one approach to dealing with outliers in archival settings. As such, we follow the guidance in Leone et al. (2018) and perform robust regression to ensure our results are not unduly affected by influential observations. We estimate a first-stage robust regression using MM-estimation of bank reliance on each complexity measure, along with all control variables, and obtain the robust regression weights. These weights reduce the influence of observations that do not fit with the majority of the data. In the second stage, we estimate the models columns (1) through (4) using weighted least squares. In untabulated analysis, we find that results for columns (1) through (3) remain positive and significant. We do not find a significant positive relation for column (4). These results indicate that our inferences are not significantly affected by influential observations.

${ }^{20}$ Following Bharath et al. (2008), we control for accounting quality in our analyses. However, our proxy of accounting quality and research design choices are not directly comparable.
} 
Columns (2) and (4) regress loan interest rate on FS Length and Bog Index. Financial statement length and readability are both significantly and positively related to interest rate $(p<.01$ and $p<.05$, respectively). We estimate that one SD higher FS Length leads to 7.9 bps higher interest rates, and one SD higher Bog Index leads to 3.9 bps higher interest rates. These results suggest lenders charge a premium for financial statement complexity.

\subsection{Control rights and collateral requirements}

This section investigates whether loan contracting terms relating to control rights and collateral requirements are sensitive to financial statement complexity. Prior literature argues that contracts are inherently incomplete because they can't incorporate all relevant parameters, and efficient contracts allocate control based on realized states of the world (Aghion and Bolton, 1992). Complexity exacerbates the incomplete contracting problem because it leads to information asymmetry between lenders and borrowers (Garleanu and Zwiebel, 2008). When information asymmetry is high between lenders and borrowers, lenders will demand greater ex post control (Garleanu and Zwiebel, 2008). Accordingly, we predict that banks will respond to complexity-driven information asymmetry by increasing their control rights through more and tighter covenants and by requiring collateral against the borrowings.

Table 5 estimates equation (2), where we test whether financial statement complexity is associated with covenant intensity, tightness and collateral requirements. In columns (1) and (4), the dependent variable is the covenant intensity, or number of covenants. In columns (2) and (5), the dependent variable is the $e x$ ante probability of covenant violation, which is a measure of covenant tightness proposed by Demerjian and Owens (2016). In columns (3) and (6), we employ a linear probability model where the dependent variable is an indicator variable equal to one if the loan is secured, and zero otherwise. ${ }^{21}$

We first consider the number and tightness of covenants. Column (2) shows that banks impose tighter covenants on firms in response to higher financial statement length. Column (4) demonstrates that banks also impose more covenants in response to lower financial statement readability. These results suggest banks prefer to maintain bargaining power with the firm as renegotiating opportunities present themselves more frequently with more and tighter covenants (Dichev and Skinner, 2002). Turning next to collateral, we

\footnotetext{
${ }^{21}$ Inferences are similar if we use a logit model.
} 
note that loans to complex borrowers also require collateral more frequently, as shown in columns (3) and (6). In sum, we find that banks can employ a variety of contracting terms to address financial statement complexity. This evidence is also consistent with financial statement complexity capturing information asymmetry relevant to debt contracting.

\section{Additional and sensitivity analyses}

\subsection{Bank debt reliance over time}

We conduct six additional analyses that extend and support our main findings. First, we examine the effect of growing financial statement complexity over time on firms' reliance on bank debt. There is a trend upwards in firms' reliance on bank debt during the period 2004-2015. However, it is not clear whether firms' bank reliance may decline over time as equity and public debt markets may catch up in addressing complexity. Another possibility is that as complexity increases banks become more specialized in processing information. Thus, the evolution of bank reliance over time for complex firms is an empirical question.

Complex firms increase their levels of bank debt at a comparatively faster rate (see Figure 3 for an illustration of this trend). Table 6 reports multivariate analyses supporting this finding. Columns (1) and (3) estimate the impact of complexity as measured by statement length. The even columns estimate the impact of BogIndex on bank reliance. Both complexity measures are divided by 1000 to facilitate presentation of the coefficients. Columns (1) and (2) include industry fixed effects, and columns (3) and (4) include firm fixed effects. Since the focus of attention is the time-trend, we do not include year fixed effects in these specifications.

The coefficient of interest in the interaction term between statement complexity and time. Column (1) suggests that over time, bank reliance is increasing for firms per unit statement complexity. Thus, equity and public debt markets are unable to reduce the relative advantage of banks in processing complex information. In fact, banks are providing a larger share of financing to such firms. Column (2) finds similar results with our second measure of complexity. Columns (3) and (4) remain robust to the inclusion of firm fixed effects. They suggest that the findings are not driven by time-invariant characteristics of firms. In sum, as firms become more complex, the equilibrium shifts further towards bank financing per unit of complexity. This suggests that banks are fulfilling their traditional role of informed financing in a changing economy. 


\subsection{Relationship lending}

We next examine the link between complexity and relationship lending. We argue that firms with comparatively high financial statement complexity rely more on bank debt, because banks mitigate information asymmetry problems. Further, the literature has shown that having a relationship with a bank allows the firm-bank pair to reduce information frictions. ${ }^{22}$ Therefore, if firms are truly attempting to mitigate complexity-related information asymmetry through bank financing, we should observe that complex firms rely more heavily on relationship lending.

To conduct this test, we merge Capital IQ, COMPUSTAT and Dealscan data sets to create a panel of all existing lending relationships for each borrower. We keep only firm-year observations that occur within the start date and maturity date of a Dealscan loan facility. This results in a sample size with 14,594 firm-year observations. Following prior literature, we are interested in the relationship between lead arrangers and our sample of borrowers. For each loan facility, we use two measures to capture the relationship between the lead arranger and borrower.

Table 7 presents our relationship tests. Columns (1)-(2) utilize statement length as the measure of complexity, and the next two columns use the Bog Index. In columns (1) and (3), the strength of the relationship Relationship (\#) is measured as the number of loans associated with the lead arranger in the prior five years scaled by the total number of loans in the same period. Columns (2) and (4) utilize Relationship (\$) measured as the dollar amount of loans associated with the lead arranger in the prior five years scaled by the total dollar amount of loans in the the same period. Both relationship measures are calculated as of the origination of each loan. For firms with multiple lead arrangers for their outstanding loans, we use the maximum Relationship (\#) and Relationship (\$) following Bharath et al. (2011) for each firm-year observation. We $\log$ both ratios for better distributional properties.

The results in columns (1) and (2) suggest that firms with high financial statement complexity form stronger relationships with their banks. Columns (3) and (4) document similar results for readability. One concern may be that firms with higher statement complexity have less access to other banks and hence lead

\footnotetext{
${ }^{22}$ Bharath et al. (2011) demonstrate that firms which repeatedly borrow from the same lead arranger (lead bank of the loan syndicate) benefit through lower interest rates, increase loan amounts and lower collateral requirements. Further, Bharath et al. (2007) demonstrate that firms with high information asymmetries are more likely to borrow from lenders with which they have prior relationships.
} 
banks have to take a larger share. Untabulated analysis suggests this is not the case; even though firms are borrowing more from their lead banks, complex firms work with a larger number of lead banks for financing.

\subsection{Disentangling business and accounting standards complexity}

We next seek to disentangle the source of complexity compelling firms to seek bank financing. As discussed previously, textual-based proxies based on the annual report narrative, such as 10-K length and Bog Index, capture various forms of complexity, including complexity arising from a firms' intricacy of accounting standards, business operations and communication of performance, and managerial discretion (e.g. obfuscation). We argue that it is unlikely that managerial obfuscation is driving our positive relation between complexity and bank reliance because it would be counter-intuitive that a manager intending to hide poor true performance would seek financing from a source best-equipped to unmask it. However, we distinguish between complexity arising from (a) intricacy of the applicable accounting standards and (b) the firms' business operations and discussions of performance.

We measure the different sources of complexity by parsing the 10-K into two parts. First, we use textual analysis techniques to remove and count the word length of the footnotes to the financial statements in each 10-K (i.e. Item 8). We use the natural $\log$ of the words in the accounting footnotes as a measure of the intricacy of accounting standards (Standards Complexity). We calculate business operations and performance complexity as the natural $\log$ of the total number of words in the $10-\mathrm{K}$ less the number of words in the footnotes (Business Complexity). We limit our analysis to firms that include their accounting footnote disclosures in Item 8, as it allows for more reliable parsing. ${ }^{23}$ This results in a sample of 16,369 firm-year observations. Based on our parsing procedures, the accounting footnotes represent approximately $24 \%$ of the total textual content of the $10-\mathrm{K}$.

We present the results of our analysis in Table 8. We use the same model as equation 1 . The independent variables of interest in columns (1) and (3) are Business Complexity and Standards Complexity, and in columns (2) and (4) are Bog Index and Standards Complexity. Columns (1) and (2) include industry-year fixed effects, while columns (3) and (4) include year and firm fixed effects. In columns (1) and (3), the coefficient on our measure of business complexity is positive and significant ( $p<.01$ and $p<.05$, respectively).

\footnotetext{
${ }^{23}$ Firms can refer to an exhibit, such as an attached annual report, in their 10-K filings.
} 
The coefficients on our measure of accounting standard intricacy are small and insignificant. Further, readability continues to be positive and significant even after considering the intricacy of accounting standards. The results suggest business operations and performance complexity is the primary source of complexity associated with firms' bank financing.

\subsection{Non-bank debt reliance}

The evidence in our main analyses is consistent with firms mitigating information frictions by using bank debt. However, our complexity measures may be capturing some correlated omitted variable that influences both financial statement disclosure characteristics and debt financing. Accordingly, we seek to bolster our inferences by using the relation between non-bank debt reliance and complexity as a falsification test. ${ }^{24}$ Bondholders are dispersed and lack the technology and monitoring associated with bank financing (Diamond, 1991). Consistent with this, Bonsall and Miller (2017) find that complexity is penalized in the bond market through credit rating agency disagreement and higher bond yields at issuance. As such, we have no a priori reason to expect firms to mitigate complexity-driven information problems with non-bank debt.

To test the relation between complexity and non-bank debt reliance, we employ the same specification as equation 1, except the dependent variable is the firm-year observation's non-bank debt (total debt less bank debt) scaled by total assets. Columns (1) and (2) include on industry-year fixed effects, while columns (3) and (4) include industry-year and firm fixed effects. We do not expect the coefficient on our complexity variables to load significantly in any specification.

Table 9 presents the results of our public debt reliance tests. In columns (1) and (3), we find no significant relation between financial statement length and non-bank debt reliance. Both coefficients on financial statement length are smaller than those in the main specification in Table 3. Results are less clear for readability. Column (2) reports a positive but insignificant coefficient, however the within-firm analysis in column (4) reports a significant and positive significant coefficient $(p<.05)$. While the results are not fully conclusive, we do believe that these results help mitigate the concern that our complexity measures are simply capturing firm characteristics associated with debt financing. Further, we show in a later analysis that the significant

\footnotetext{
${ }^{24}$ Non-bank debt comprises mostly of senior and subordinated bonds and notes (approximately $91 \%$ in our sample). Additional debt types include commercial paper, capital leases, and "other" debt.
} 
relation between readability and non-bank debt is not robust to covariate balancing.

\subsection{Alternative Specifications}

\subsubsection{Alternative measures of bank reliance}

Our next set of tests consider alternative measures of bank reliance. The results are presented in Table 10. First, in columns (1) and (2), we scale bank debt by total debt, instead of by total assets (Bank Debt \% of Total Debt). This sharpens the focus on the choice between bank and corporate debt faced by the firm. However, it does not consider the amount of assets financed by bank debt, which is the reason why we scale bank debt by total assets in the main tests. Second, in columns (3) and (4), we utilize the natural logarithm of total bank debt as an alternative measure of bank reliance ( $L n$ Bank Debt) to address the possibility our results are driven by using a scalar. Last, we remove all firms without any debt using our main measure of bank debt reliance (Bank Reliance). We include industry-year fixed effects in all models. Our inferences are insensitive to these alternative bank reliance measures and specifications.

\subsubsection{Long-term bank reliance}

A potential concern is that bank debt drives the properties of disclosure, specifically making disclosure more complex. We explore this possibility by examining whether financial statement complexity is associated with short- and long-term increase in borrowing from banks. If financial statement complexity increases due to contemporaneous bank debt borrowing, we should not see a relation between complexity and future bank reliance. Further, since capital structure adjustments can be gradual over time, empirical tests with longer term changes can provide more statistical power.

These analyses are presented in Table 11. We measure future debt borrowings as total bank debt in the future firm-year less bank debt in the current firm-year, scaled by total assets in the current firm-year (Debt Growth). Importantly, since we are comparing future bank borrowing to debt borrowing in the year we are measuring financial statement complexity, this specification controls for any contemporaneous association between disclosure and bank borrowing. The independent variables are measured as of the current

firm-year. We examine future borrowings for a period of 1-5 years. In other words, the dependent variable for columns (1) and (2) is one year debt growth, columns (3) and (4) is two year debt growth, and so on. 
We include industry-year fixed effects in all models. We find that length and readability are positively associated with future debt borrowings for both the short- and long-term. Further, the relationship between complexity and borrowing strengthens over time. Thus, it appears unlikely that our inferences are driven by reverse-causality.

\subsection{Covariate balancing}

We use entropy balancing to mitigate the effect of differences in characteristics between firms with high and low levels of complexity (Hainmueller, 2012; McMullin and Schonberger, 2015). Selection bias potentially affects our inferences, despite having firm fixed effects and several characteristics as controls in our main analyses. Covariate balancing aims to "match" firms with high and low levels of complexity in our sample. Shipman et al. (2016) primarily highlight that covariate balancing and other related techniques, such as propensity score matching, are not intended to fix endogeneity problems (e.g., correlated omitted variables and selection bias). However, entropy balancing is helpful in mitigating the likelihood of model misspecification due to the linearity constraint imposed by OLS multiple regression, known as functionalform misspecification. This concern is usually driven by large differences in the characteristics among "treated" and "control" groups. As such, we check if our results are robust to balancing the covariates among firms with high and low financial statement complexity. ${ }^{25}$

Entropy balancing requires a binary classification of "treated" and "control" groups. Since our complexity measures are continuous, we create annual terciles of our measures of length and readability and remove observations in the middle tercile as those are likely to be the most similar firms. Firms in the highest tercile of complexity are classified as High Length and High Bog (and given a value of one), while firms in the lowest tercile are given a value of zero. This creates treated and control groups in terms of length and readability.

After establishing treated and control groups, we run a first-stage model to determine weights for each observation in the second stage based on balancing on the first moment. This model is identical to our specification in 1 including all previously identified control variables, except we use industry and year fixed

\footnotetext{
${ }^{25}$ Entropy balancing is advantageous over alternative covariate balancing techniques such as propensity score matching because it allows you to retain the entire sample.
} 
effects (no firm fixed effects). ${ }^{26}$ In Table 12, columns (1) and (2), we show that our indicator variables exhibit consistent relations with bank reliance relative to our main results without entropy balancing weights. The results of the entropy-balanced specification for bank reliance and complexity is presented in Table 12 in columns (3) and (4). Consistent with our main results, length and readability are positively and significantly related to bank reliance. Overall, the evidence supports the notion that financial statement complexity is related to bank financing and help rule out the possibility our results are driven by inherent differences between relatively more and less complex firms.

We perform a similar analysis for non-bank debt. As discussed earlier, we do not expect complex firms to more heavily rely on non-bank sources. However, we found some evidence in Table 9 that readability was related to non-bank financing. We investigate whether length and readability, after balancing covariates amongst high complexity and low complexity firms, are related to non-bank financing reliance. Columns (5) and (6) demonstrate the baseline regression without covariate balancing, and columns (7) and (8) present results after incorporating covariate balancing. Consistent with our prediction, there is no relation between financial statement length or readability and non-bank financing.

In Table 13, we present the covariate balancing results for our contracting outcomes. For parsimony, we do not show the results of regressions without the entropy-balanced weighting. Results are largely consistent with our predictions and prior evidence (results on interest rate and collateral requirements do not have statistical significance even though they are economically significant). The lack of statistical power on interest rate may be explained by previous literature on bank lending that suggests that lenders prefer to use quantity rather than price as a mechanism in relationship lending (Petersen and Rajan, 1994).

\section{Conclusion}

A number of recent studies and anecdotal evidence show that investors struggle to process increasingly long and complex financial reports. Existing theory and evidence suggests that banks have a unique advantage in acquiring and processing information at a lower cost than equity and public debt market investors. Hence, as financial statement complexity of a firm increases, bank financing can be more attractive relative to other sources of financing. While the first-best solution remains conveying information clearly and

\footnotetext{
${ }^{26}$ The use of too many fixed effects reduces the likelihood of convergence in the first stage. We use industry-year fixed effects in the second stage.
} 
succinctly, complex firms and banks have moved towards a constrained equilibrium.

We focus on two dimensions of financial statement complexity that capture the volume and presentation of financial statement information $-10-\mathrm{K}$ length and readability. First, we find that comparatively higher financial statement complexity is associated with higher firm reliance on bank financing, both across and within firms. Our results on financial statement complexity are incremental to controlling for traditional proxies for business complexity, such as size and number of segments. Our findings are consistent with firms reducing information frictions linked to financial statement complexity by relying more heavily on banks for financing.

Second, we investigate the association between contractual terms of bank financing and complexity. We expect contractual differences based on firm financial statement complexity if banks exert more effort to screen and monitor complex borrowers. These contractual differences will be in two dimensions: (a) features that are determined ex ante (e.g. loan amount and interest rate), and (b) features that enhance bargaining power in ex post renegotiations (e.g. covenants and collateral). We focus on five contractual terms to test whether banks respond to complexity: the amount, the rate, the number and tightness of covenants imposed on the firms, and the collateral requirements for a sample of bank loans. We find evidence consistent with banks screening loans more carefully and rationing credit supply in presence of higher financial statement complexity. Moreover, banks impose tighter covenants and demand collateral to maintain bargaining power given incomplete lending contracts.

Overall, our results suggest that banks continue to play their role as informed capital providers in a changing economy, characterized by growing financial statement complexity and innovations in the banks' business model. 


\section{References}

Aghion, P., Bolton, P., 1992. An incomplete contracts approach to financial contracting. The Review of Economic Studies 59, 473-494.

Akerlof, G. A., 1970. The market for "lemons": Quality uncertainty and the market mechanism. The Quarterly Journal of Economics 84, 488-500.

Altman, E. I., 1968. Financial ratios, discriminant analysis and the prediction of corporate bankruptcy. The Journal of Finance 23, 589-609.

Baylis, R. M., Burnap, P., Clatworthy, M. A., Gad, M. A., Pong, C. K., 2017. Private lenders demand for audit. Journal of Accounting and Economics 64, 78-97.

Benmelech, E., Dlugosz, J., Ivashina, V., 2012. Securitization without adverse selection: The case of CLOs. Journal of Financial Economics 106, 91 - 113.

Berger, A. N., Udell, G. F., 1990. Collateral, loan quality and bank risk. Journal of Monetary Economics 25, $21-42$.

Bharath, S., Dahiya, S., Saunders, A., Srinivasan, A., 2007. So what do I get? The bank's view of lending relationships. Journal of Financial Economics 85, 368-419.

Bharath, S., Dahiya, S., Saunders, A., Srinivasan, A., 2011. Lending relationships and loan contract terms. Review of Financial Studies 24, 1141-1203.

Bharath, S. T., Hertzel, M., 2018. External governance and debt structure. The Review of Financial Studies forthcoming.

Bharath, S. T., Sunder, J., Sunder, S. V., 2008. Accounting quality and debt contracting. The Accounting Review 83, 1-28.

Bonsall, S. B., Leone, A. J., Miller, B. P., Rennekamp, K., 2017. A plain english measure of financial reporting readability. Journal of Accounting and Economics 63, 329-357.

Bonsall, S. B., Miller, B. P., 2017. The impact of narrative disclosure readability on bond ratings and the cost of debt. Review of Accounting Studies 22, 608-643.

Boot, A. W. A., Thakor, A. V., 2000. Can relationship banking survive competition? The Journal of Finance $55,679-713$.

Bozanic, Z., Loumioti, M., Vasvari, F. P., 2018. Corporate loan securitization and the standardization of financial covenants. Journal of Accounting Research 56, 45-83.

Bozanic, Z., Thevenot, M., 2015. Qualitative disclosure and changes in sell-side financial analysts' information environment. Contemporary Accounting Research 32, 1595-1616.

Bushee, B. J., Gow, I. D., Taylor, D. J., 2018. Linguistic complexity in firm disclosures: Obfuscation or information? Journal of Accounting Research 56, 85-121.

Chava, S., Roberts, M. R., 2008. How does financing impact investment? The role of debt covenants. The Journal of Finance 63, 2085-2121. 
Christensen, H. B., Nikolaev, V. V., 2012. Capital versus performance covenants in debt contracts. Journal of Accounting Research 50, 75-116.

Christensen, H. B., Nikolaev, V. V., Wittenberg-Moerman, R., 2016. Accounting information in financial contracting: The incomplete contract theory perspective. Journal of Accounting Research 54, 397-435.

Chychyla, R., Leone, A. J., Minutti-Meza, M., 2018. Complexity of financial reporting standards and accounting expertise. Journal of Accounting and Economics, forthcoming .

Cohen, L., Lou, D., 2012. Complicated firms. Journal of Financial Economics 104, 383 - 400.

Colla, P., Ippolito, F., Li, K., 2013. Debt specialization. The Journal of Finance 68, 2117-2141.

Corwin, S. A., Coughenour, J. F., 2008. Limited attention and the allocation of effort in securities trading. Journal of Finance 63, 3031-3067.

Costello, A. M., Wittenberg-Moerman, R., 2011. The impact of financial reporting quality on debt contracting: Evidence from internal control weakness reports. Journal of Accounting Research 49, 97-136.

DeAngelo, H., DeAngelo, L., Whited, T., 2011. Capital structure dynamics and transitory debt. Journal of Financial Economics 99, 235-261.

Demerjian, P. R., 2011. Accounting standards and debt covenants: Has the balance sheet approach led to a decline in the use of balance sheet covenants? Journal of Accounting and Economics 52, 178-202.

Demerjian, P. R., Owens, E. L., 2016. Measuring the probability of financial covenant violation in private debt contracts. Journal of Accounting and Economics 61, 433-447.

Denis, D. J., Mihov, V. T., 2003. The choice among bank debt, non-bank private debt, and public debt: Evidence from new corporate borrowings. Journal of Financial Economics 70, 3-28.

Dewatripont, M., Tirole, J., 1994. A theory of debt and equity: Diversity of securities and managershareholder congruence. Quarterly Journal of Economics 109, 1027-1054.

Diamond, D. W., 1984. Financial intermediation and delegated monitoring. The Review of Economic Studies 51, 393-414.

Diamond, D. W., 1985. Optimal release of information by firms. The Journal of Finance 40, 1071-1094.

Diamond, D. W., 1991. Monitoring and reputation: The choice between bank loans and directly placed debt. Journal of Political Economy 99, 689-721.

Dichev, I. D., Skinner, D. J., 2002. Large-sample evidence on the debt covenant hypothesis. Journal of Accounting Research 40, 1091-1123.

Dyer, T., Lang, M., Stice-Lawrence, L., 2017. The evolution of 10-K textual disclosure: Evidence from Latent Dirichlet Allocation. Journal of Accounting and Economics 64, 221 - 245.

Fama, E. F., 1985. What's different about banks? Journal of Monetary Economics 15, 29 - 39.

Filzen, J. J., Peterson, K., 2015. Financial statement complexity and meeting analysts expectations. Contemporary Accounting Research 32, 1560-1594. 
Gande, A., Saunders, A., 2012. Are banks still special when there is a secondary market for loans? The Journal of Finance 67, 1649-1684.

Garleanu, N., Zwiebel, J., 2008. Design and renegotiation of debt covenants. The Review of Financial Studies 22, 749-781.

Gorton, G., Kahn, J., 2000. The design of bank loan contracts. The Review of Financial Studies 13, 331-364.

Guay, W., Samuels, D., Taylor, D., 2016. Guiding through the fog: Financial statement complexity and voluntary disclosure. Journal of Accounting and Economics 62, 234-269.

Hainmueller, J., 2012. Entropy balancing for causal effects: A multivariate reweighting method to produce balanced samples in observational studies. Political Analysis 20, 25-46.

Hart, O., Moore, J., 1988. Incomplete contracts and renegotiation. Econometrica 56, 755-85.

Hellmann, T. F., Murdock, K. C., Stiglitz, J. E., 2000. Liberalization, moral hazard in banking, and prudential regulation: Are capital requirements enough? The American Economic Review 90, 147-165.

Hirshleifer, D., Teoh, S. H., 2003. Limited attention, information disclosure, and financial reporting. Journal of Accounting and Economics 36, 337 - 386.

Hwang, B.-H., Kim, H. H., 2017. It pays to write well. Journal of Financial Economics 124, 373-394.

Ivashina, V., 2009. Asymmetric information effects on loan spreads. Journal of Financial Economics 92, 300-319.

James, C., 1987. Some evidence on the uniqueness of bank loans. Journal of Financial Economics 19, 217235.

John, K., Williams, J., 1985. Dividends, dilution, and taxes: A signalling equilibrium. The Journal of Finance 40, 1053-1070.

Keys, B. J., Mukherjee, T., Seru, A., Vig, V., 2010. Did securitization lead to lax screening? Evidence from subprime loans. The Quarterly Journal of Economics 125, 307-362.

Kim, O., Verrecchia, R. E., 1991. Market reaction to anticipated announcements. Journal of Financial Economics 30, 273-309.

Lawrence, A., 2013. Individual investors and financial disclosure. Journal of Accounting and Economics 56, $130-147$.

Lee, Y.-J., 2012. The effect of quarterly report readability on information efficiency of stock prices. Contemporary Accounting Research 29, 1137-1170.

Lehavy, R., Li, F., Merkley, K., 2011. The effect of annual report readability on analyst following and the properties of their earnings forecasts. The Accounting Review 86, 1087-1115.

Leland, H., Pyle, D. H., 1977. Informational asymmetries, financial structure, and financial intermediation. Journal of Finance 32, 371-87. 
Leone, A., Minutti-Meza, M., Wasley, C., 2018. Influential observations and inference in accounting research. Working paper .

Li, F., 2008. Annual report readability, current earnings, and earnings persistence. Journal of Accounting and Economics 45, 221-247.

Lo, K., Ramos, F., Rogo, R., 2017. Earnings management and annual report readability. Journal of Accounting and Economics 63, 1-25.

Loughran, T., McDonald, B., 2014. Measuring readability in financial disclosures. The Journal of Finance 69, 1643-1671.

McMullin, J. L., Schonberger, B., 2015. Entropy-balanced discretionary accruals. Working paper .

Miller, B. P., 2010. The effects of reporting complexity on small and large investor trading. The Accounting Review 85, 2107-2143.

Modigliani, F., Miller, M. H., 1963. Corporate income taxes and the cost of capital: A correction. The American Economic Review 53, 433-443.

Myers, S. C., 1977. Determinants of corporate borrowing. Journal of Financial Economics 5, 147-175.

Myers, S. C., Majluf, N. S., 1984. Corporate financing and investment decisions when firms have information that investors do not have. Journal of Financial Economics 13, $187-221$.

Nini, G., Smith, D. C., Sufi, A., 2009. Creditor control rights and firm investment policy. Journal of Financial Economics 92, 400-420.

Nini, G., Smith, D. C., Sufi, A., 2012. Creditor control rights, corporate governance, and firm value. The Review of Financial Studies 25, 1713-1761.

Petersen, M. A., Rajan, R. G., 1994. The benefits of lending relationships: Evidence from small business data. The Journal of Finance 49, 3-37.

Peterson, K., 2012. Accounting complexity, misreporting, and the consequences of misreporting. Review of Accounting Studies 17, 72-95.

Purnanandam, A., 2011. Originate-to-distribute model and the subprime mortgage crisis. The Review of Financial Studies 24, 1881-1915.

Rajan, R., Winton, A., 1995. Covenants and collateral as incentives to monitor. The Journal of Finance 50, 1113-1146.

Rajan, R. G., 1992. Insiders and outsiders: The choice between informed and arm's-length debt. The Journal of Finance 47, 1367-1400.

Rajan, R. G., Zingales, L., 1995. What do we know about capital structure? Some evidence from international data. The Journal of Finance 50, 1421-1460.

Ramakrishnan, R. T. S., Thakor, A. V., 1984. Information reliability and a theory of financial intermediation. The Review of Economic Studies 51, 415-432. 
Rauh, J. D., Sufi, A., 2010. Capital structure and debt structure. The Review of Financial Studies 23, 42424280 .

Ross, S. A., 1977. The determination of financial structure: The incentive-signalling approach. The Bell Journal of Economics 8, 23-40.

Rothschild, M., Stiglitz, J., 1976. Equilibrium in competitive insurance markets: An essay on the economics of imperfect information. The Quarterly Journal of Economics 90, 629-649.

Securities and Exchange Commission, 2013. Report on review of disclosure requirements in Regulation S-K. Tech. rep., SEC.

Sharpe, S. A., 1990. Asymmetric information, bank lending, and implicit contracts: A stylized model of customer relationships. The Journal of Finance 45, 1069-1087.

Shipman, J. E., Swanquist, Q. T., Whited, R. L., 2016. Propensity score matching in accounting research. The Accounting Review 92, 213-244.

Shyam-Sunder, L., Myers, S. C., 1999. Testing static tradeoff against pecking order models of capital structure. Journal of Financial Economics 51, 219 - 244.

Stiglitz, J., Weiss, A., 1981. Credit rationing in markets with imperfect information. American Economic Review 71, 393-410.

Stiglitz, J., Weiss, A., 1983. Incentive effects of terminations: Applications to the credit and labor markets. American Economic Review 73, 912-27.

You, H., Zhang, X., 2009. Financial reporting complexity and investor underreaction to 10-K information. Review of Accounting Studies 14, 559-586. 


\section{Appendix A: Variable definitions}

This table provides the definitions of the variables used in our empirical analyses. All firm fundamental and characteristic variables are calculated as of the fiscal year prior to the loan issuance.

\begin{tabular}{|c|c|c|}
\hline Variable & Definition & Source \\
\hline \multicolumn{3}{|c|}{ Financial Statement Complexity Variables } \\
\hline Business Complexity & $\begin{array}{l}\text { Natural } \log \text { of the total number of words less the number of words in the foot- } \\
\text { notes to the financial statements in the } 10-\mathrm{K} \text { filed as of the most recent fiscal } \\
\text { year end. }\end{array}$ & $\begin{array}{l}\text { Self- } \\
\text { constructed }\end{array}$ \\
\hline Bog Index & Readability measure based on Bonsall et al. (2017). & $\begin{array}{l}\text { Bonsall et al. } \\
(2017)\end{array}$ \\
\hline FS Length & $\begin{array}{l}\text { Natural log of the number of words in the } 10-\mathrm{K} \text { filed as of the most recent fiscal } \\
\text { year end. }\end{array}$ & $\begin{array}{l}\text { Loughran and } \\
\text { McDonald } \\
(2014)\end{array}$ \\
\hline Raw Number of Words & $\begin{array}{l}\text { Number of words (in thousands) in the } 10-\mathrm{K} \text { filed as of the most recent fiscal } \\
\text { year end. }\end{array}$ & $\begin{array}{l}\text { Loughran and } \\
\text { McDonald } \\
(2014)\end{array}$ \\
\hline Standards Complexity & $\begin{array}{l}\text { Natural log of the total number of words in the footnotes to the financial state- } \\
\text { ments in the } 10-\mathrm{K} \text { filed as of the most recent fiscal year end. }\end{array}$ & $\begin{array}{l}\text { Self- } \\
\text { constructed }\end{array}$ \\
\hline
\end{tabular}

Firm Fundamentals and Characteristics

Book Leverage

Book to Market

Business Segments

Discretionary Accruals

EBITDA

Firm Size

Geographic Segments

Loss

Returns

Return Volatility

Special Items
Sum of long term debt (DLTT) and short term debt (DLC) scaled by assets (AT).

Total book equity (CEQ) scaled by market value of equity (PRCC * CSHO).

Natural log of the number of business segments identified in COMPUSTAT.

Absolute value of performance and industry-adjusted discretionary accruals.

Sales (SALE) less cost of good sold (COGS) less selling, general and administrative expenses (SGA), scaled by total assets (AT).

Natural log of the total assets (AT) for the firm-year observation.

COMPUSTAT

Natural log of the number of geographic segments identified in COMPUSTAT.

Indicator variable equal to one if income before extraordinary items (IB) is less than zero, and zero otherwise.

Cumulative monthly stock returns for the fiscal-year ended.

CRSP

Standard deviation of monthly stock returns for the fiscal-year ended.

Special items (SPI) scaled by total assets (AT).
COMPUSTAT

CRSP

COMPUSTAT

COMPUSTAT

COMPUSTAT

COMPUSTAT

COMPUSTAT

COMPUSTAT

COMPUSTAT 


\begin{tabular}{lll}
\hline Variable & Definition & Source \\
\hline Tangibility & Total net property, plant and equipment (PPENT) scaled by total assets (AT). & COMPUSTAT \\
Unrated & $\begin{array}{l}\text { Indicator variable equal to one if there is no S\&P credit rating available for any } \\
\text { period within the most recent prior fiscal year, and zero otherwise. }\end{array}$ & COMPUSTAT \\
Zscore & Probability of default as constructed in Altman (1968). & COMPUSTAT \\
\hline
\end{tabular}

\section{Debt Reliance and Relationship Variables}

\begin{tabular}{|c|c|c|}
\hline $\begin{array}{l}\text { Bank Debt \% of Total } \\
\text { Debt }\end{array}$ & Total bank debt scaled by total debt. & S\&P Capital IQ \\
\hline Bank Reliance & Total bank debt scaled by total assets. & S\&P Capital IQ \\
\hline Debt Growth & $\begin{array}{l}\text { Total bank debt at time } t+z \text { less total bank debt at time } t \text {, scaled by total assets } \\
\text { at time } t \text {. }\end{array}$ & S\&P Capital IQ \\
\hline Ln Bank Debt & Natural log of one plus total bank debt. & S\&P Capital IQ \\
\hline Non-Bank Debt & Total debt less total bank debt scaled by total assets. & S\&P Capital IQ \\
\hline Relationship (Amount) & $\begin{array}{l}\text { Dollar amount of loans associated with each lead arranger of existing outstand- } \\
\text { ing debt in the prior five years, scaled by the total dollar amount of loans in the } \\
\text { same prior five year period similar to the approach by Bharath et al. (2011). We } \\
\text { log the resulting ratio. If there are multiple lead arrangers we use the maximum } \\
\text { value. }\end{array}$ & Dealscan \\
\hline Relationship (Number) & $\begin{array}{l}\text { Number of loans associated with each lead arranger of existing outstanding debt } \\
\text { in the prior five years, scaled by the total number of loans in the same prior five } \\
\text { year period similar to the approach by Bharath et al. (2011). We log the resulting } \\
\text { ratio. If there are multiple lead arrangers we use the maximum value. }\end{array}$ & Dealscan \\
\hline
\end{tabular}

\section{Loan Variables}

Institutional

Investor

Lending

Frequency

Loan Size

Maturity

NumCov

PP Indicator
Indicator variable equal to one if the loan type (LoanType) includes the terms "Term Loan B", "Term Loan C", “Term Loan D", and zero otherwise. These represent term loans where the lender is an institutional investor.

Natural log of one plus the number of loans the borrower has entered into in the prior five years.

Natural log of the loan amount (FacilityAmt).

Dealscan

Time from debt issuance to maturity in months (Maturity).

Dealscan

Total number of financial covenants included in the loan package.

Dealscan

Indicator variable equal to one if the loan includes a performance pricing provi- Dealscan sion (PerformancePricingType), and zero otherwise. 


\begin{tabular}{lll}
\hline Variable & Definition & Source \\
\hline Pviol & $\begin{array}{l}\text { Probability of covenant violation upon loan inception as measured in Demerjian } \\
\text { and Owens (2016). }\end{array}$ & $\begin{array}{l}\text { Demerjian and } \\
\text { Owens (2016) }\end{array}$ \\
Revolver Dummy & $\begin{array}{l}\text { Indicator variable equal to one if the loan type (LoanType) includes the term } \\
\text { "Revolver", and zero otherwise. }\end{array}$ & Dealscan \\
Secured Loan & $\begin{array}{l}\text { Indicator variable equal to one if the loan is secured (Secured = "Yes"), and zero } \\
\text { otherwise. }\end{array}$ & Dealscan \\
Syndicated Loan & $\begin{array}{l}\text { Indicator variable equal to one if there is more than one lender associated with } \\
\text { the loan observation, and zero otherwise. }\end{array}$ & Dealscan \\
Volatility Ratio & $\begin{array}{l}\text { Volatility ratio of financial statement items as measured in Demerjian (2011). } \\
\text { COMPUSTAT }\end{array}$
\end{tabular}


Figure 1: Growing Financial Statement Complexity Over Time

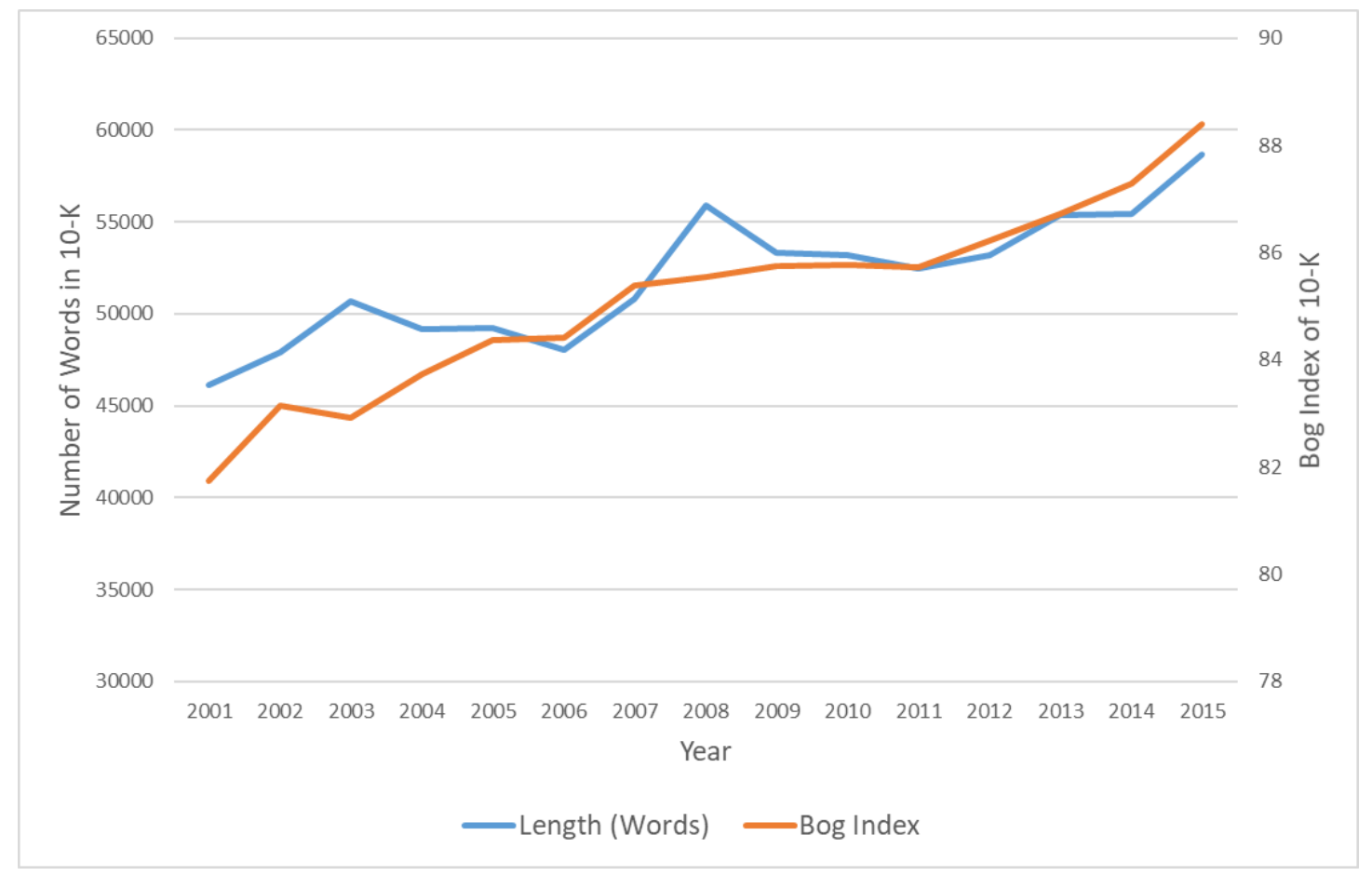

This graph illustrates the mean length (in number of words) and Bog Index of annual financial statements in our sample over the time period of the study. 
Figure 2: Bank Reliance and Financial Statement Complexity

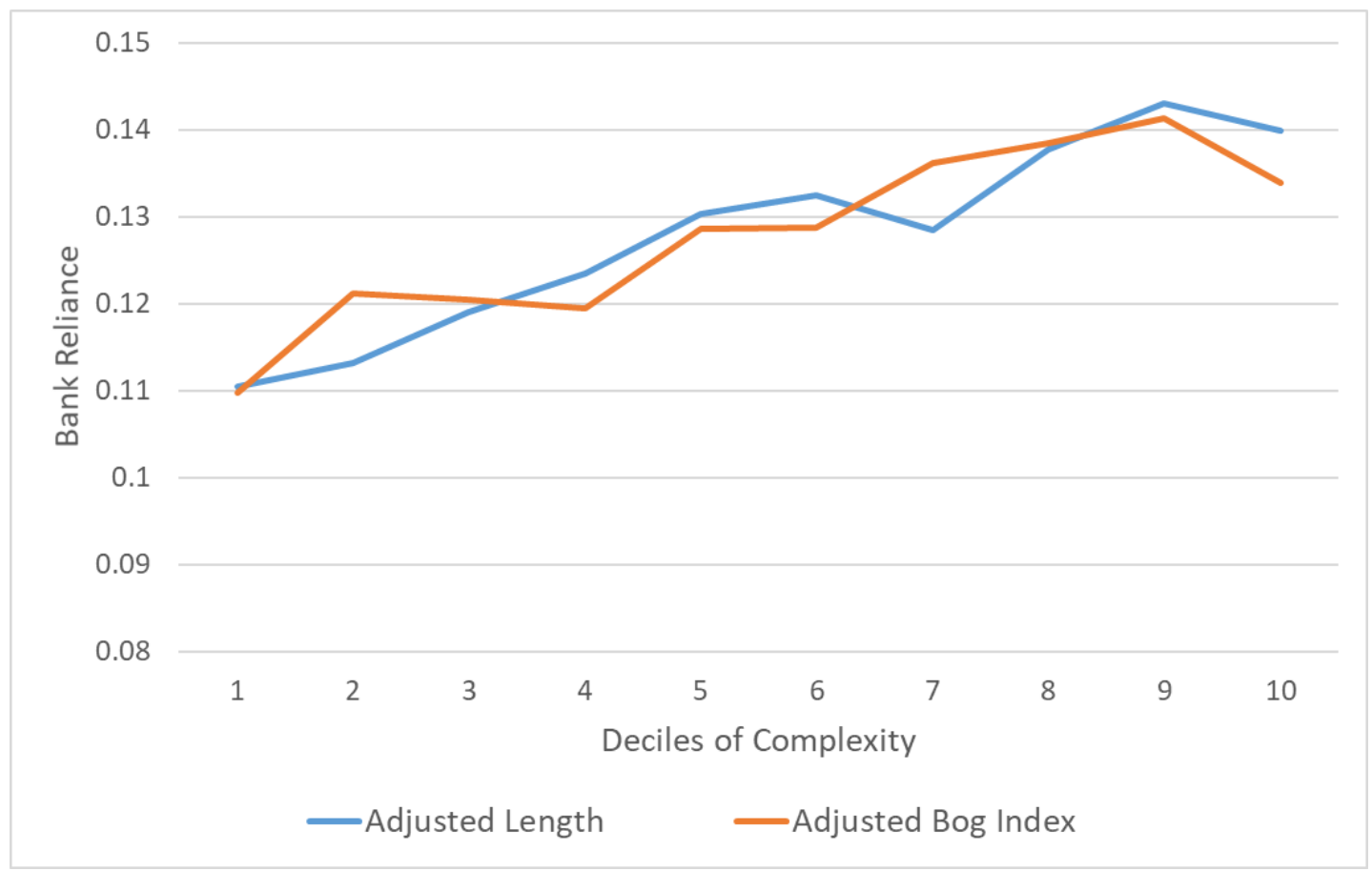

This graph illustrates the relation between bank debt as a fraction of assets and deciles of adjusted financial statement length and readability. This displays the association between complexity and bank debt reliance after controlling for differences in firm size, and profitability as well as aggregate differences at the industry-year level. 
Figure 3: Bank Reliance and Financial Statement Complexity Over Time
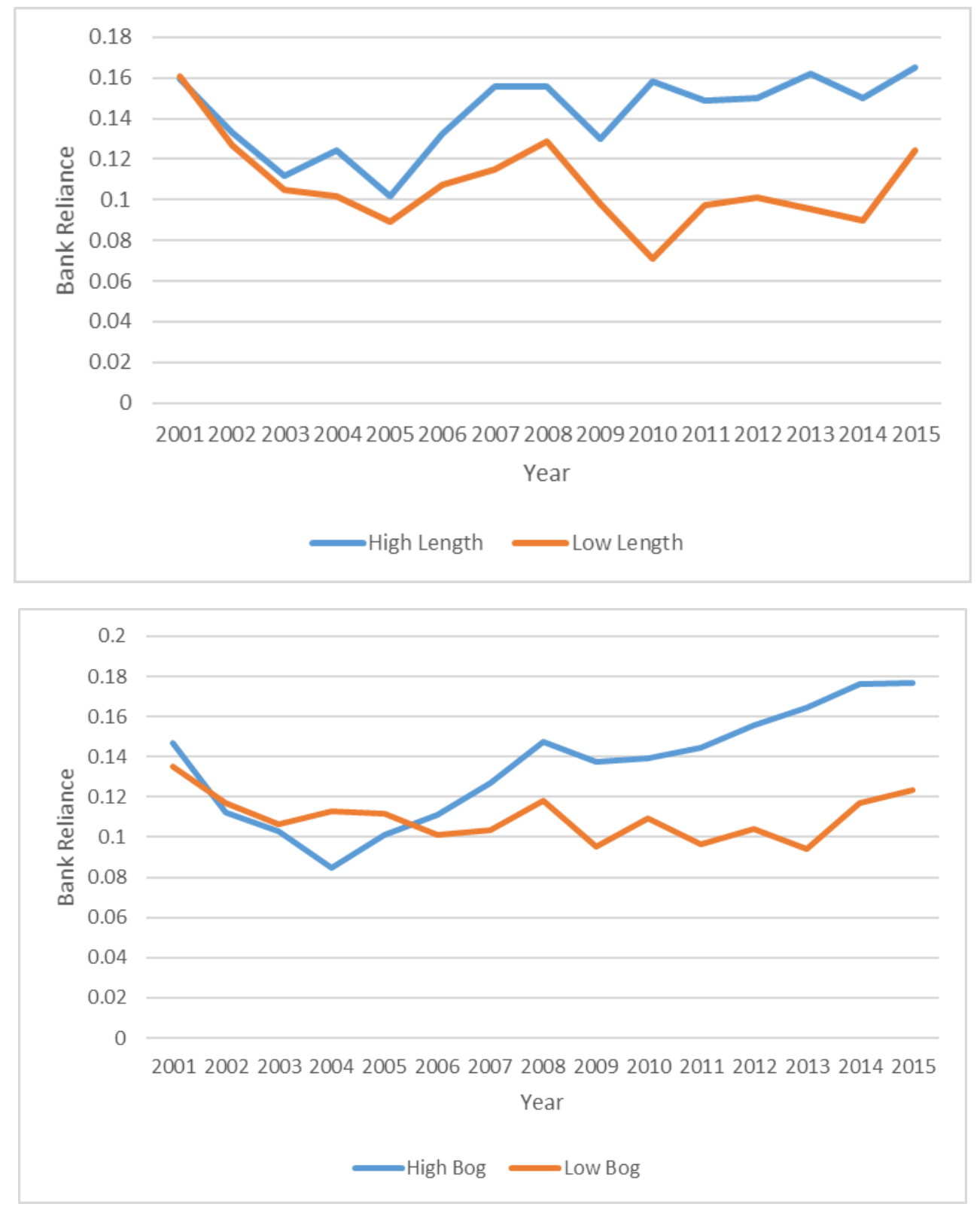

The top graph illustrates the relation between bank debt as a fraction of assets and adjusted financial statement length over time. The bottom graph illustrates the relation between bank debt as a fraction of assets and adjusted financial statement Bog Index over time. Both adjusted complexity measures control for differences in firm size, and profitability as well as aggregate differences at the firm industry-year level. High Length (Bog) corresponds to firm-year observations in the top decile of adjusted financial statement length (Bog Index), and Low Length (Bog) corresponds to firm-year observations in the bottom decile of adjusted financial statement length (Bog Index). 
Figure 4: Bank Debt as a Percentage of Total Debt and Financial Statement Complexity Over Time
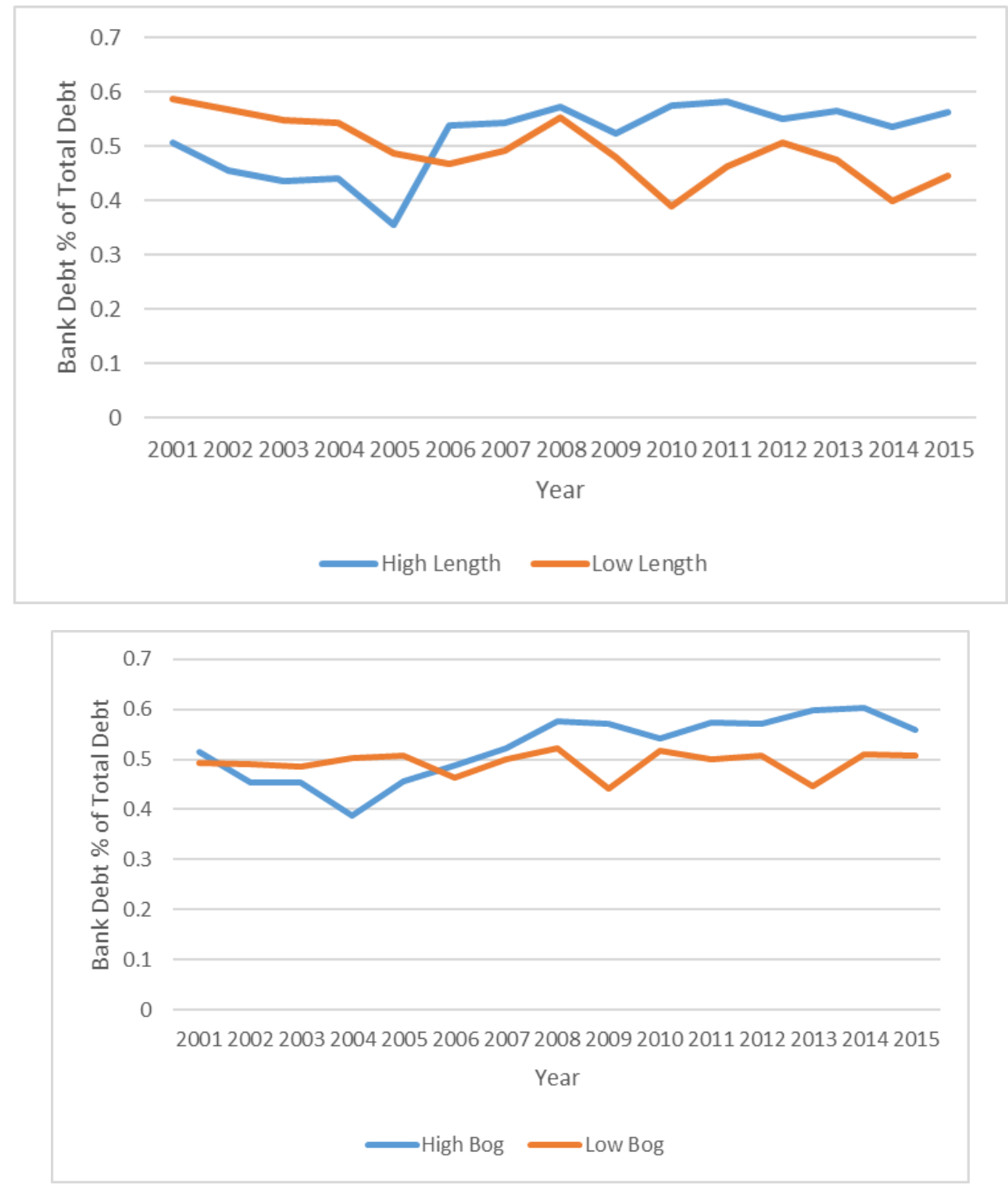

The top graph illustrates the relation between bank debt as a fraction of total debt and adjusted financial statement length over time. The bottom graph illustrates the relation between bank debt as a fraction of total debt and adjusted financial statement Bog Index over time. Both adjusted complexity measures control for differences in firm size, and profitability as well as aggregate differences at the firm industry-year level. High Length (Bog) corresponds to firm-year observations in the top decile of adjusted financial statement length (Bog Index), and Low Length (Bog) corresponds to firm-year observations in the bottom decile of adjusted financial statement length (Bog Index). 
Table 1: Sample Selection

\begin{tabular}{lcc}
\hline Bank Reliance Sample Selection & Observations & Unique Firms \\
\hline Compustat observations with non-missing AT (2001-2015) & 117,225 & 15,339 \\
Less missing Capital IQ summary data & $-54,352$ & $-5,870$ \\
Less missing 10-K FS textual data & $-14,216$ & $-1,820$ \\
Less missing total bank debt & $-10,463$ & $-1,081$ \\
Less Compustat-Capital IQ difference greater than 10\% & -127 & -19 \\
Less financial firms & $-9,821$ & $-1,072$ \\
Less missing control variable data & $-6,471$ & $-1,260$ \\
\hline Bank reliance final sample & 21,775 & 4,217 \\
\hline
\end{tabular}

\begin{tabular}{lcc}
\hline Loan Contracting Sample Selection & Observations & Unique Firms \\
\hline Loan observations with non-missing Compustat AT (1995-2016) & 33,628 & 6,523 \\
Less missing 10-K FS textual data & $-16,782$ & $-2,599$ \\
Less financial firms & $-1,995$ & -420 \\
Keep only largest loan observation & $-4,826$ & -0 \\
Less missing control variable data & $-1,303$ & -654 \\
\hline Loan contracting final sample & 8,722 & 2,850 \\
\hline
\end{tabular}

This table shows the construction of both samples. 
Table 2: Descriptive Statistics

Panel A: Bank Reliance Sample

\begin{tabular}{|c|c|c|c|c|c|}
\hline & Mean & SD & $\mathrm{P} 25$ & Median & P75 \\
\hline \multicolumn{6}{|l|}{ Financial Statement Complexity } \\
\hline Raw Number of Words (000's) & 52.066 & 36.662 & 31.645 & 43.574 & 61.400 \\
\hline FS Length & 10.706 & 0.522 & 10.362 & 10.682 & 11.025 \\
\hline Bog Index & 85.206 & 6.481 & 81.000 & 85.000 & 89.000 \\
\hline \multicolumn{6}{|l|}{ Debt Reliance } \\
\hline Bank Reliance & 0.128 & 0.146 & 0.013 & 0.076 & 0.192 \\
\hline Non-Bank Debt & 0.140 & 0.169 & 0.001 & 0.074 & 0.239 \\
\hline Book Leverage & 0.268 & 0.207 & 0.105 & 0.237 & 0.381 \\
\hline \multicolumn{6}{|c|}{ Firm Fundamentals and Characteristics } \\
\hline Zscore & 2.636 & 4.103 & 1.148 & 2.498 & 4.136 \\
\hline Firm Size & 6.361 & 1.959 & 4.876 & 6.369 & 7.737 \\
\hline EBITDA & 0.071 & 0.185 & 0.055 & 0.106 & 0.157 \\
\hline Book to Market & 0.601 & 0.807 & 0.271 & 0.483 & 0.786 \\
\hline Tangibility & 0.299 & 0.251 & 0.096 & 0.216 & 0.456 \\
\hline Loss & 0.336 & 0.472 & 0.000 & 0.000 & 1.000 \\
\hline Special Items & -0.025 & 0.259 & -0.014 & -0.002 & 0.000 \\
\hline Returns & 0.055 & 0.557 & -0.252 & -0.022 & 0.236 \\
\hline Return Volatility & 0.122 & 0.082 & 0.067 & 0.100 & 0.151 \\
\hline Business Segments & 0.608 & 0.697 & 0.000 & 0.000 & 1.099 \\
\hline Geographic Segments & 0.623 & 0.723 & 0.000 & 0.000 & 1.099 \\
\hline Unrated & 0.641 & 0.480 & 0.000 & 1.000 & 1.000 \\
\hline Discretionary Accruals & 0.164 & 0.226 & 0.037 & 0.091 & 0.197 \\
\hline Observations & 21,775 & & & & \\
\hline
\end{tabular}

This table presents descriptive statistics for the main bank reliance dependent, independent and control variables. Continuous variables are winsorized at the $1 \%$ and $99 \%$ levels. Variable descriptions are in Appendix A. 
Panel B: Loan Contracting Sample

\begin{tabular}{|c|c|c|c|c|c|}
\hline & Mean & $S D$ & $P 25$ & Median & $P 75$ \\
\hline \multicolumn{6}{|l|}{ Financial Statement Complexity } \\
\hline Raw Number of Words (000’s) & 38.274 & 36.846 & 18.699 & 30.010 & 47.261 \\
\hline FS Length & 10.656 & 0.656 & 10.244 & 10.666 & 11.075 \\
\hline Bog Index & 83.359 & 7.209 & 79.000 & 83.000 & 88.000 \\
\hline \multicolumn{6}{|c|}{ Firm Fundamentals and Characteristics } \\
\hline Book Leverage & 0.281 & 0.202 & 0.135 & 0.262 & 0.393 \\
\hline Book to Market & 0.560 & 0.768 & 0.284 & 0.471 & 0.734 \\
\hline Tangibility & 0.323 & 0.251 & 0.117 & 0.244 & 0.494 \\
\hline Loss & 0.225 & 0.417 & 0.000 & 0.000 & 0.000 \\
\hline EBITDA & 0.127 & 0.093 & 0.086 & 0.125 & 0.172 \\
\hline Firm Size & 6.776 & 1.849 & 5.478 & 6.776 & 8.052 \\
\hline Business Segments & 2.635 & 2.137 & 1.000 & 2.000 & 4.000 \\
\hline Geographic Segments & 2.360 & 1.914 & 1.000 & 1.000 & 3.000 \\
\hline Return Volatility & 0.112 & 0.069 & 0.065 & 0.095 & 0.139 \\
\hline Returns & 1.089 & 0.576 & 0.782 & 0.991 & 1.245 \\
\hline Unrated & 0.531 & 0.499 & 0.000 & 1.000 & 1.000 \\
\hline ZScore & 3.372 & 3.309 & 1.536 & 2.697 & 4.282 \\
\hline Special Items & -0.017 & 0.057 & -0.012 & -0.001 & 0.000 \\
\hline Discretionary Accruals & 0.133 & 0.174 & 0.034 & 0.079 & 0.165 \\
\hline \multicolumn{6}{|l|}{ Loan Characteristics } \\
\hline Revolver Dummy & 0.710 & 0.454 & 0.000 & 1.000 & 1.000 \\
\hline Institutional Investor & 0.075 & 0.263 & 0.000 & 0.000 & 0.000 \\
\hline Maturity & 46.664 & 21.106 & 36.000 & 56.000 & 60.000 \\
\hline Loan Size & 18.989 & 1.606 & 17.910 & 19.114 & 20.125 \\
\hline Syndicated Loan & 0.786 & 0.410 & 1.000 & 1.000 & 1.000 \\
\hline Secured Loan & 0.580 & 0.494 & 0.000 & 1.000 & 1.000 \\
\hline Lending Frequency & 1.187 & 0.585 & 0.693 & 1.099 & 1.609 \\
\hline PP Indicator & 0.642 & 0.479 & 0.000 & 1.000 & 1.000 \\
\hline Volatility Ratio & 2.028 & 2.159 & 0.999 & 1.304 & 2.156 \\
\hline Interest Rate & 191.632 & 132.057 & 100.000 & 175.000 & 250.000 \\
\hline PViol & 0.361 & 0.413 & 0.011 & 0.106 & 0.895 \\
\hline NumCov & 2.118 & 0.894 & 1.000 & 2.000 & 3.000 \\
\hline Observations & 8,722 & & & & \\
\hline
\end{tabular}

This table presents descriptive statistics for the main loan contracting dependent, independent and control variables. Continuous variables are winsorized at the $1 \%$ and $99 \%$ levels. Variable descriptions are in Appendix A. 
Table 3: Bank Debt Reliance

\begin{tabular}{|c|c|c|c|c|}
\hline & $\begin{array}{c}(1) \\
\text { Bank Reliance }\end{array}$ & $\begin{array}{c}(2) \\
\text { Bank Reliance }\end{array}$ & $\begin{array}{c}(3) \\
\text { Bank Reliance }\end{array}$ & $\begin{array}{c}\text { (4) } \\
\text { Bank Reliance }\end{array}$ \\
\hline \multicolumn{5}{|c|}{ Financial Statement Complexity } \\
\hline FS Length & $\begin{array}{l}0.012^{* * *} \\
(3.69)\end{array}$ & & $\begin{array}{l}0.006^{* * *} \\
(2.61)\end{array}$ & \\
\hline Bog Index & & $\begin{array}{l}0.001^{* * *} \\
(4.13)\end{array}$ & & $\begin{array}{l}0.000 \\
(1.21)\end{array}$ \\
\hline \multicolumn{5}{|c|}{ Firm Fundamentals and Characteristics } \\
\hline Zscore & $\begin{array}{l}-0.011^{\text {*** }} \\
(-20.74)\end{array}$ & $\begin{array}{l}-0.011^{* * *} \\
(-20.95)\end{array}$ & $\begin{array}{l}-0.011^{* * *} \\
(-16.12)\end{array}$ & $\begin{array}{l}-0.011^{* * *} \\
(-16.06)\end{array}$ \\
\hline Firm Size & $\begin{array}{l}-0.013^{* * *} \\
(-8.23)\end{array}$ & $\begin{array}{l}-0.013^{* * *} \\
(-8.10)\end{array}$ & $\begin{array}{l}0.016^{* * *} \\
(3.80)\end{array}$ & $\begin{array}{l}0.016^{* * *} \\
(3.80)\end{array}$ \\
\hline EBITDA & $\begin{array}{l}0.178^{* * *} \\
(12.05)\end{array}$ & $\begin{array}{l}0.181^{* * *} \\
(12.18)\end{array}$ & $\begin{array}{l}0.056^{* * *} \\
(3.30)\end{array}$ & $\begin{array}{l}0.056^{* * *} \\
(3.27)\end{array}$ \\
\hline Book to Market & $\begin{array}{l}-0.013^{* * *} \\
(-5.23)\end{array}$ & $\begin{array}{l}-0.012^{* * *} \\
(-5.21)\end{array}$ & $\begin{array}{l}-0.010^{* * *} \\
(-4.06)\end{array}$ & $\begin{array}{l}-0.010^{* * *} \\
(-4.10)\end{array}$ \\
\hline Tangibility & $\begin{array}{l}0.037^{* * *} \\
(2.99)\end{array}$ & $\begin{array}{l}0.040^{* * *} \\
(3.23)\end{array}$ & $\begin{array}{c}0.022 \\
(0.90)\end{array}$ & $\begin{array}{c}0.022 \\
(0.90)\end{array}$ \\
\hline Loss & $\begin{array}{l}0.008^{* *} \\
(2.26)\end{array}$ & $\begin{array}{l}0.008^{* *} \\
(2.22)\end{array}$ & $\begin{array}{l}0.014^{* * *} \\
(4.93)\end{array}$ & $\begin{array}{l}0.014^{* * *} \\
(4.96)\end{array}$ \\
\hline Special Items & $\begin{array}{c}0.009 \\
(1.63)\end{array}$ & $\begin{array}{r}0.008 \\
(1.54)\end{array}$ & $\begin{array}{c}0.004 \\
(1.13)\end{array}$ & $\begin{array}{c}0.004 \\
(1.08)\end{array}$ \\
\hline Returns & $\begin{array}{l}-0.005^{* *} \\
(-2.19)\end{array}$ & $\begin{array}{l}-0.005^{* *} \\
(-2.33)\end{array}$ & $\begin{array}{c}0.000 \\
(0.25)\end{array}$ & $\begin{array}{c}0.000 \\
(0.20)\end{array}$ \\
\hline Return Volatility & $\begin{array}{l}0.125^{* * *} \\
(5.80)\end{array}$ & $\begin{array}{l}0.128^{* * *} \\
(5.91)\end{array}$ & $\begin{array}{l}0.075^{* * *} \\
(4.04)\end{array}$ & $\begin{array}{l}0.076^{* * *} \\
(4.08)\end{array}$ \\
\hline Business Segments & $\begin{array}{l}-0.002 \\
(-0.63)\end{array}$ & $\begin{array}{l}-0.002 \\
(-0.95)\end{array}$ & $\begin{array}{c}0.003 \\
(0.77)\end{array}$ & $\begin{array}{c}0.003 \\
(0.78)\end{array}$ \\
\hline Geographic Segments & $\begin{array}{l}-0.014^{* * *} \\
(-5.40)\end{array}$ & $\begin{array}{l}-0.014^{* * *} \\
(-5.39)\end{array}$ & $\begin{array}{l}-0.001 \\
(-0.32)\end{array}$ & $\begin{array}{l}-0.001 \\
(-0.32)\end{array}$ \\
\hline Unrated & $\begin{array}{r}0.009 \\
(1.51)\end{array}$ & $\begin{array}{r}0.009 \\
(1.43)\end{array}$ & $\begin{array}{l}0.017^{* *} \\
(1.97)\end{array}$ & $\begin{array}{l}0.017^{\text {** }} \\
(1.98)\end{array}$ \\
\hline Discretionary Accruals & $\begin{array}{l}-0.011^{* *} \\
(-2.08)\end{array}$ & $\begin{array}{l}-0.011^{* *} \\
(-2.09)\end{array}$ & $\begin{array}{c}0.000 \\
(0.07)\end{array}$ & $\begin{array}{c}0.000 \\
(0.06)\end{array}$ \\
\hline Industry-Year FEs & Yes & Yes & No & No \\
\hline Year FEs & No & No & Yes & Yes \\
\hline Firm FEs & No & No & Yes & Yes \\
\hline Adj. $R^{2}$ & 0.19 & 0.19 & 0.67 & 0.67 \\
\hline Observations & 21,775 & 21,775 & 21,775 & 21,775 \\
\hline
\end{tabular}

This table presents the regression results examining whether firms with comparatively high financial statement complexity have a higher proportion of bank debt. The independent variable of interest in columns (1) and (3) is the borrower's financial statement length (FS Length), and the borrower's financial statement Bog Index (Bog Index) in columns (2) and (4). The dependent variable is the total amount of bank debt held by a firm scaled by total assets (Bank Reliance). Columns (1) and (2) include industry-year (Fama-French 30) fixed effects, and columns (3) and (4) include year and firm fixed effects. Standard errors are clustered by firm in all specifications. Variable definitions are in Appendix A. 
Table 4: Loan Price and Quantity

\begin{tabular}{|c|c|c|c|c|}
\hline & $\begin{array}{c}(1) \\
\text { Loan Size }\end{array}$ & $\begin{array}{c}(2) \\
\text { Interest Rate }\end{array}$ & $\begin{array}{c}(3) \\
\text { Loan Size }\end{array}$ & $\begin{array}{c}\text { (4) } \\
\text { Interest Rate }\end{array}$ \\
\hline \multicolumn{5}{|c|}{ Financial Statement Complexity } \\
\hline FS Length & $\begin{array}{l}-0.040^{* *} \\
(-2.39)\end{array}$ & $\begin{array}{l}8.157^{* * *} \\
(4.18)\end{array}$ & & \\
\hline Bog Index & & & $\begin{array}{l}-0.004^{* *} \\
(-2.11)\end{array}$ & $\begin{array}{l}0.455^{* *} \\
(2.35)\end{array}$ \\
\hline \multicolumn{5}{|c|}{ Firm Fundamentals and Characteristics } \\
\hline Book Leverage & $\begin{array}{l}0.338^{* * *} \\
(4.60)\end{array}$ & $\begin{array}{l}50.553^{* * *} \\
(5.48)\end{array}$ & $\begin{array}{l}0.340^{* * *} \\
(4.63)\end{array}$ & $\begin{array}{l}50.470^{* * *} \\
(5.47)\end{array}$ \\
\hline Book to Market & $\begin{array}{l}-0.035^{* *} \\
(-2.18)\end{array}$ & $\begin{array}{r}2.297 \\
(0.98)\end{array}$ & $\begin{array}{l}-0.034^{* *} \\
(-2.12)\end{array}$ & $\begin{array}{l}1.932 \\
(0.83)\end{array}$ \\
\hline Tangibility & $\begin{array}{l}-0.108 \\
(-1.57)\end{array}$ & $\begin{array}{l}-11.596 \\
(-1.45)\end{array}$ & $\begin{array}{l}-0.118^{*} \\
(-1.70)\end{array}$ & $\begin{array}{l}-10.626 \\
(-1.32)\end{array}$ \\
\hline Loss & $\begin{array}{l}-0.086^{* * *} \\
(-3.01)\end{array}$ & $\begin{array}{l}43.004^{* * *} \\
(9.88)\end{array}$ & $\begin{array}{l}-0.087^{* * *} \\
(-3.04)\end{array}$ & $\begin{array}{l}43.445^{* * *} \\
(9.94)\end{array}$ \\
\hline EBITDA & $\begin{array}{l}0.558^{* * *} \\
(4.02)\end{array}$ & $\begin{array}{c}-113.349^{* * *} \\
(-5.83)\end{array}$ & $\begin{array}{l}0.560^{* * *} \\
(4.02)\end{array}$ & $\begin{array}{c}-115.225^{* * *} \\
(-5.92)\end{array}$ \\
\hline Firm Size & $\begin{array}{c}0.576^{* * *} \\
(45.29)\end{array}$ & $\begin{array}{l}-9.427^{* * *} \\
(-5.37)\end{array}$ & $\begin{array}{l}0.572^{* * *} \\
(44.90)\end{array}$ & $\begin{array}{l}-8.481^{* * *} \\
(-4.85)\end{array}$ \\
\hline Business Segments & $\begin{array}{c}-0.001 \\
(-0.28)\end{array}$ & $\begin{array}{c}0.741 \\
(1.33)\end{array}$ & $\begin{array}{l}-0.001 \\
(-0.15)\end{array}$ & $\begin{array}{c}0.712 \\
(1.28)\end{array}$ \\
\hline Geographic Segments & $\begin{array}{l}-0.014^{* *} \\
(-2.44)\end{array}$ & $\begin{array}{r}0.672 \\
(0.74)\end{array}$ & $\begin{array}{l}-0.014^{* *} \\
(-2.42)\end{array}$ & $\begin{array}{r}0.667 \\
(0.74)\end{array}$ \\
\hline Return Volatility & $\begin{array}{l}-0.441^{* *} \\
(-2.44)\end{array}$ & $\begin{array}{l}310.186^{* * *} \\
(10.65)\end{array}$ & $\begin{array}{l}-0.445^{\text {** }} \\
(-2.46)\end{array}$ & $\begin{array}{l}313.077^{* * *} \\
(10.78)\end{array}$ \\
\hline Returns & $\begin{array}{c}0.006 \\
(0.39)\end{array}$ & $\begin{array}{l}-10.687^{* * *} \\
(-4.66)\end{array}$ & $\begin{array}{c}0.007 \\
(0.40)\end{array}$ & $\begin{array}{l}-10.673^{* * *} \\
(-4.67)\end{array}$ \\
\hline Unrated & $\begin{array}{l}-0.016 \\
(-0.54)\end{array}$ & $\begin{array}{c}0.753 \\
(0.21)\end{array}$ & $\begin{array}{l}-0.017 \\
(-0.56)\end{array}$ & $\begin{array}{c}0.875 \\
(0.24)\end{array}$ \\
\hline ZScore & $\begin{array}{c}0.007^{*} \\
(1.65)\end{array}$ & $\begin{array}{l}-2.636^{* * *} \\
(-4.82)\end{array}$ & $\begin{array}{c}0.007^{*} \\
(1.73)\end{array}$ & $\begin{array}{l}-2.704^{* * *} \\
(-4.94)\end{array}$ \\
\hline Special Items & $\begin{array}{l}-0.434^{* *} \\
(-2.21)\end{array}$ & $\begin{array}{c}40.294 \\
(1.35)\end{array}$ & $\begin{array}{l}-0.434^{* *} \\
(-2.23)\end{array}$ & $\begin{array}{c}39.645 \\
(1.33)\end{array}$ \\
\hline Discretionary Accruals & $\begin{array}{l}-0.053 \\
(-0.99)\end{array}$ & $\begin{array}{l}19.409^{* * *} \\
(2.64)\end{array}$ & $\begin{array}{l}-0.055 \\
(-1.02)\end{array}$ & $\begin{array}{l}19.876^{* * *} \\
(2.69)\end{array}$ \\
\hline Loan Characteristics & & & & \\
\hline Revolver Dummy & $\begin{array}{l}0.161^{* * *} \\
(6.52)\end{array}$ & $\begin{array}{l}-33.883^{* * *} \\
(-8.62)\end{array}$ & $\begin{array}{l}0.162^{* * *} \\
(6.59)\end{array}$ & $\begin{array}{l}-34.043^{\text {**** }} \\
(-8.67)\end{array}$ \\
\hline Institutional Investor & $\begin{array}{l}0.334^{* * *} \\
(7.78)\end{array}$ & $\begin{array}{l}58.617^{\text {*** }} \\
(7.21)\end{array}$ & $\begin{array}{l}0.333^{* * *} \\
(7.75)\end{array}$ & $\begin{array}{l}58.956^{* * *} \\
(7.24)\end{array}$ \\
\hline Maturity & $\begin{array}{l}0.007^{* * *} \\
(12.15)\end{array}$ & $\begin{array}{c}0.122 \\
(1.35)\end{array}$ & $\begin{array}{l}0.007^{* * *} \\
(12.16)\end{array}$ & $\begin{array}{c}0.114 \\
(1.25)\end{array}$ \\
\hline Syndicated Loan & $\begin{array}{c}0.764^{* * * *} \\
(21.94)\end{array}$ & $\begin{array}{c}3.045 \\
(0.65)\end{array}$ & $\begin{array}{l}0.764^{* * *} \\
(21.88)\end{array}$ & $\begin{array}{l}3.001 \\
(0.64)\end{array}$ \\
\hline Secured Loan & $\begin{array}{c}0.004 \\
(0.15)\end{array}$ & $\begin{array}{l}47.363^{* * *} \\
(16.55)\end{array}$ & $\begin{array}{c}0.003 \\
(0.13)\end{array}$ & $\begin{array}{l}47.766^{* * *} \\
(16.62)\end{array}$ \\
\hline Lending Frequency & $\begin{array}{l}0.157^{* * *} \\
(7.76)\end{array}$ & $\begin{array}{l}8.206^{* * *} \\
(3.70)\end{array}$ & $\begin{array}{l}0.155^{* * *} \\
(7.63)\end{array}$ & $\begin{array}{l}8.614^{* * *} \\
(3.90)\end{array}$ \\
\hline PP Indicator & $\begin{array}{l}0.162^{* * *} \\
(7.81)\end{array}$ & $\begin{array}{l}-27.933^{* * *} \\
(-8.89)\end{array}$ & $\begin{array}{l}0.161^{* * *} \\
(7.78)\end{array}$ & $\begin{array}{l}-27.779^{* * *} \\
(-8.80)\end{array}$ \\
\hline Volatility Ratio & $\begin{array}{r}0.001 \\
(0.26)\end{array}$ & $\begin{array}{c}0.753 \\
(1.19)\end{array}$ & $\begin{array}{l}0.001 \\
(0.22)\end{array}$ & $\begin{array}{r}0.761 \\
(1.20)\end{array}$ \\
\hline Loan Size & & $\begin{array}{l}-12.809^{* * *} \\
(-6.35)\end{array}$ & & $\begin{array}{l}-12.820^{* * *} \\
(-6.34)\end{array}$ \\
\hline Loan Purpose FEs & Yes & Yes & Yes & Yes \\
\hline Industry-Year FEs & Yes & Yes & Yes & Yes \\
\hline Adj. $\mathrm{R}^{2}$ & 0.84 & 0.56 & 0.84 & 0.56 \\
\hline Observations & 8,722 & 8,341 & 8,722 & 8,341 \\
\hline
\end{tabular}

This table presents the regression results examining whether firms with comparatively high financial statement complexity pay higher interest rates for bank debt and obtain lower loan amounts. The independent variable of interest in columns (1) and (2) is the borrower's financial statement length (FS Length), and the borrower's financial statement Bog Index (Bog Index) in columns (3) and (4). In columns (1) and (3), the dependent variable is the natural log of the size of the loan (Loan Size). In columns (2) and (4) the dependent variable is interest rate associated with the loan in basis points above LIBOR (Interest Rate). Loan purpose and industry-year (Fama-French 30) fixed effects are included in each specification. Standard errors are clustered by firm in all specifications. Variable definitions are in Appendix A. 
Table 5: Control Rights and Collateral Requirements

\begin{tabular}{|c|c|c|c|c|c|c|}
\hline & $\begin{array}{c}\text { (1) } \\
\text { NumCov }\end{array}$ & $\begin{array}{c}\text { (2) } \\
\text { PViol }\end{array}$ & $\begin{array}{c}\text { (3) } \\
\text { Secured Loan }\end{array}$ & $\begin{array}{c}\text { (4) } \\
\text { NumCov }\end{array}$ & $\begin{array}{c}(5) \\
\text { PViol }\end{array}$ & $\begin{array}{c}(6) \\
\text { Secured Loan }\end{array}$ \\
\hline \multicolumn{7}{|c|}{ Financial Statement Complexity } \\
\hline FS Length & $\begin{array}{r}0.030 \\
(1.54)\end{array}$ & $\begin{array}{l}0.038^{* * *} \\
(4.36)\end{array}$ & $\begin{array}{l}0.051^{* * *} \\
(5.14)\end{array}$ & & & \\
\hline Bog Index & & & & $\begin{array}{l}0.007^{* * *} \\
(3.27)\end{array}$ & $\begin{array}{c}0.001 \\
(0.61)\end{array}$ & $\begin{array}{l}0.004^{* * *} \\
(3.52)\end{array}$ \\
\hline \multicolumn{7}{|c|}{ Firm Fundamentals and Characteristics } \\
\hline Book Leverage & $\begin{array}{l}0.311^{* * *} \\
(3.78)\end{array}$ & $\begin{array}{l}0.511^{* * *} \\
(12.70)\end{array}$ & $\begin{array}{l}0.298^{* * *} \\
(7.68)\end{array}$ & $\begin{array}{l}0.306^{* * *} \\
(3.71)\end{array}$ & $\begin{array}{l}0.512^{* * *} \\
(12.67)\end{array}$ & $\begin{array}{l}0.297^{* * *} \\
(7.63)\end{array}$ \\
\hline Book to Market & $\begin{array}{l}0.041^{* * *} \\
(2.61)\end{array}$ & $\begin{array}{l}0.045^{* * *} \\
(5.86)\end{array}$ & $\begin{array}{l}0.041^{* * *} \\
(6.45)\end{array}$ & $\begin{array}{l}0.040^{* * *} \\
(2.58)\end{array}$ & $\begin{array}{l}0.043^{* * *} \\
(5.64)\end{array}$ & $\begin{array}{l}0.040^{* * *} \\
(6.20)\end{array}$ \\
\hline Tangibility & $\begin{array}{l}-0.261^{* * *} \\
(-3.51)\end{array}$ & $\begin{array}{l}-0.085^{* *} \\
(-2.43)\end{array}$ & $\begin{array}{l}-0.048 \\
(-1.06)\end{array}$ & $\begin{array}{l}-0.242^{* * *} \\
(-3.24)\end{array}$ & $\begin{array}{l}-0.085^{* *} \\
(-2.42)\end{array}$ & $\begin{array}{l}-0.038 \\
(-0.85)\end{array}$ \\
\hline Loss & $\begin{array}{l}-0.084^{* *} \\
(-2.55)\end{array}$ & $\begin{array}{l}0.116^{* * *} \\
(6.66)\end{array}$ & $\begin{array}{l}0.062^{* * *} \\
(3.84)\end{array}$ & $\begin{array}{l}-0.086^{* * *} \\
(-2.62)\end{array}$ & $\begin{array}{l}0.119^{* * *} \\
(6.85)\end{array}$ & $\begin{array}{l}0.064^{* * *} \\
(3.92)\end{array}$ \\
\hline EBITDA & $\begin{array}{l}0.469^{* * *} \\
(3.14)\end{array}$ & $\begin{array}{l}-0.716^{* * *} \\
(-7.90)\end{array}$ & $\begin{array}{l}-0.429^{* * *} \\
(-5.43)\end{array}$ & $\begin{array}{l}0.480^{* * *} \\
(3.22)\end{array}$ & $\begin{array}{l}-0.730^{* * *} \\
(-8.03)\end{array}$ & $\begin{array}{l}-0.436^{* * *} \\
(-5.53)\end{array}$ \\
\hline Firm Size & $\begin{array}{l}-0.126^{* * *} \\
(-7.27)\end{array}$ & $\begin{array}{l}-0.004 \\
(-0.48)\end{array}$ & $\begin{array}{l}-0.129^{* * *} \\
(-15.93)\end{array}$ & $\begin{array}{l}-0.126^{* * *} \\
(-7.35)\end{array}$ & $\begin{array}{c}0.002 \\
(0.22)\end{array}$ & $\begin{array}{l}-0.124^{* * *} \\
(-15.27)\end{array}$ \\
\hline Business Segments & $\begin{array}{l}-0.000 \\
(-0.03)\end{array}$ & $\begin{array}{c}0.005 \\
(1.59)\end{array}$ & $\begin{array}{l}-0.000 \\
(-0.03)\end{array}$ & $\begin{array}{l}-0.002 \\
(-0.30)\end{array}$ & $\begin{array}{l}0.005^{*} \\
(1.65)\end{array}$ & $\begin{array}{l}-0.001 \\
(-0.19)\end{array}$ \\
\hline Geographic Segments & $\begin{array}{l}-0.003 \\
(-0.37)\end{array}$ & $\begin{array}{c}0.001 \\
(0.16)\end{array}$ & $\begin{array}{l}-0.006 \\
(-1.52)\end{array}$ & $\begin{array}{l}-0.003 \\
(-0.39)\end{array}$ & $\begin{array}{r}0.001 \\
(0.18)\end{array}$ & $\begin{array}{l}-0.006 \\
(-1.55)\end{array}$ \\
\hline Return Volatility & $\begin{array}{l}-0.691^{* * *} \\
(-3.23)\end{array}$ & $\begin{array}{l}0.289^{* * *} \\
(2.79)\end{array}$ & $\begin{array}{l}0.967^{* * *} \\
(10.13)\end{array}$ & $\begin{array}{l}-0.706^{* * *} \\
(-3.32)\end{array}$ & $\begin{array}{l}0.305^{* * *} \\
(2.95)\end{array}$ & $\begin{array}{l}0.979^{* * *} \\
(10.19)\end{array}$ \\
\hline Returns & $\begin{array}{l}0.052^{* *} \\
(2.54)\end{array}$ & $\begin{array}{l}-0.005 \\
(-0.53)\end{array}$ & $\begin{array}{c}0.010 \\
(1.11)\end{array}$ & $\begin{array}{l}0.051^{* *} \\
(2.49)\end{array}$ & $\begin{array}{l}-0.005 \\
(-0.46)\end{array}$ & $\begin{array}{c}0.010 \\
(1.12)\end{array}$ \\
\hline Unrated & $\begin{array}{l}0.140^{* * *} \\
(4.13)\end{array}$ & $\begin{array}{l}0.054^{* * *} \\
(3.39)\end{array}$ & $\begin{array}{l}-0.033^{*} \\
(-1.73)\end{array}$ & $\begin{array}{l}0.141^{* * *} \\
(4.16)\end{array}$ & $\begin{array}{l}0.055^{\text {*** }} \\
(3.43)\end{array}$ & $\begin{array}{l}-0.032^{*} \\
(-1.68)\end{array}$ \\
\hline ZScore & $\begin{array}{l}-0.013^{* * *} \\
(-2.92)\end{array}$ & $\begin{array}{l}-0.009^{* * *} \\
(-3.24)\end{array}$ & $\begin{array}{l}-0.006^{* *} \\
(-2.37)\end{array}$ & $\begin{array}{l}-0.013^{* * *} \\
(-3.00)\end{array}$ & $\begin{array}{l}-0.009^{* * *} \\
(-3.39)\end{array}$ & $\begin{array}{l}-0.006^{* * *} \\
(-2.59)\end{array}$ \\
\hline Special Items & $\begin{array}{r}0.341 \\
(1.61)\end{array}$ & $\begin{array}{c}0.138 \\
(1.33)\end{array}$ & $\begin{array}{r}0.117 \\
(1.39)\end{array}$ & $\begin{array}{c}0.349^{*} \\
(1.65)\end{array}$ & $\begin{array}{c}0.132 \\
(1.27)\end{array}$ & $\begin{array}{c}0.115 \\
(1.38)\end{array}$ \\
\hline Discretionary Accruals & $\begin{array}{l}-0.022 \\
(-0.38)\end{array}$ & $\begin{array}{c}0.010 \\
(0.32)\end{array}$ & $\begin{array}{l}0.050^{*} \\
(1.77)\end{array}$ & $\begin{array}{l}-0.022 \\
(-0.38)\end{array}$ & $\begin{array}{c}0.013 \\
(0.41)\end{array}$ & $\begin{array}{l}0.053^{*} \\
(1.90)\end{array}$ \\
\hline Loan Characteristics & & & & & & \\
\hline Revolver Dummy & $\begin{array}{c}-0.016 \\
(-0.65)\end{array}$ & $\begin{array}{l}0.021^{*} \\
(1.72)\end{array}$ & $\begin{array}{l}0.030^{* *} \\
(2.25)\end{array}$ & $\begin{array}{c}-0.018 \\
(-0.72)\end{array}$ & $\begin{array}{c}0.019 \\
(1.59)\end{array}$ & $\begin{array}{l}0.027^{* *} \\
(2.10)\end{array}$ \\
\hline Institutional Investor & $\begin{array}{l}0.206^{* * *} \\
(3.88)\end{array}$ & $\begin{array}{r}0.017 \\
(0.70)\end{array}$ & $\begin{array}{l}0.268^{* * *} \\
(12.75)\end{array}$ & $\begin{array}{l}0.206^{* * *} \\
(3.88)\end{array}$ & $\begin{array}{r}0.017 \\
(0.70)\end{array}$ & $\begin{array}{c}0.269^{* * *} \\
(12.69)\end{array}$ \\
\hline Maturity & $\begin{array}{l}0.003^{* * *} \\
(4.80)\end{array}$ & $\begin{array}{l}0.000^{*} \\
(1.78)\end{array}$ & $\begin{array}{l}0.001^{* * *} \\
(3.55)\end{array}$ & $\begin{array}{l}0.003^{* * *} \\
(4.76)\end{array}$ & $\begin{array}{c}0.000^{*} \\
(1.76)\end{array}$ & $\begin{array}{l}0.001^{* * *} \\
(3.44)\end{array}$ \\
\hline Loan Size & $\begin{array}{c}0.010 \\
(0.55)\end{array}$ & $\begin{array}{l}-0.036^{* * *} \\
(-4.22)\end{array}$ & $\begin{array}{c}0.001 \\
(0.15)\end{array}$ & $\begin{array}{l}0.011 \\
(0.61)\end{array}$ & $\begin{array}{l}-0.038^{* * *} \\
(-4.39)\end{array}$ & $\begin{array}{r}0.001 \\
(0.13)\end{array}$ \\
\hline Syndicated Loan & $\begin{array}{l}0.252^{* * *} \\
(6.99)\end{array}$ & $\begin{array}{c}0.023 \\
(1.42)\end{array}$ & $\begin{array}{r}0.012 \\
(0.70)\end{array}$ & $\begin{array}{l}0.250^{* * *} \\
(6.93)\end{array}$ & $\begin{array}{c}0.024 \\
(1.45)\end{array}$ & $\begin{array}{c}0.011 \\
(0.66)\end{array}$ \\
\hline Secured Loan & $\begin{array}{l}0.184^{* * *} \\
(6.68)\end{array}$ & $\begin{array}{l}0.122^{* * *} \\
(8.56)\end{array}$ & & $\begin{array}{l}0.181^{* * *} \\
(6.55)\end{array}$ & $\begin{array}{l}0.126^{* * *} \\
(8.84)\end{array}$ & \\
\hline Lending Frequency & $\begin{array}{l}0.103^{* * *} \\
(4.90)\end{array}$ & $\begin{array}{c}0.016 \\
(1.51)\end{array}$ & $\begin{array}{l}0.065^{* * *} \\
(5.70)\end{array}$ & $\begin{array}{l}0.105^{* * *} \\
(4.98)\end{array}$ & $\begin{array}{c}0.018^{*} \\
(1.73)\end{array}$ & $\begin{array}{l}0.068^{* * *} \\
(5.97)\end{array}$ \\
\hline PP Indicator & $\begin{array}{l}0.181^{* * *} \\
(7.58)\end{array}$ & $\begin{array}{r}0.007 \\
(0.60)\end{array}$ & $\begin{array}{l}-0.022^{*} \\
(-1.90)\end{array}$ & $\begin{array}{l}0.182^{* * *} \\
(7.64)\end{array}$ & $\begin{array}{c}0.008 \\
(0.65)\end{array}$ & $\begin{array}{l}-0.021^{*} \\
(-1.80)\end{array}$ \\
\hline Volatility Ratio & $\begin{array}{c}-0.004 \\
(-0.90)\end{array}$ & $\begin{array}{c}-0.000 \\
(-0.09)\end{array}$ & $\begin{array}{l}-0.006^{* *} \\
(-2.35)\end{array}$ & $\begin{array}{c}-0.004 \\
(-0.83)\end{array}$ & $\begin{array}{l}-0.000 \\
(-0.06)\end{array}$ & $\begin{array}{l}-0.006^{* *} \\
(-2.26)\end{array}$ \\
\hline Loan Purpose FEs & Yes & Yes & Yes & Yes & Yes & Yes \\
\hline Industry-Year FEs & Yes & Yes & Yes & Yes & Yes & Yes \\
\hline Adj. $R^{2}$ & 0.30 & 0.36 & 0.39 & 0.30 & 0.36 & 0.38 \\
\hline Observations & 8,722 & 6,740 & 8,722 & 8,722 & 6,740 & 8,722 \\
\hline
\end{tabular}

This table presents the regression results examining whether firms with comparatively high financial statement complexity face tighter covenants and higher collateral requirements. The independent variable of interest in columns (1) - (3) is the borrower's financial statement length (FS Length), and the borrower's financial statement Bog Index (Bog Index) in columns (4) - (6). In columns (1) and (4), the dependent variable is the number of financial covenants, or covenant intensity (NumCov). In columns (2) and (5), the dependent variable is the probability of violation (Pviol) which represents the tightness of covenants upon loan origination as calculated by Demerjian and Owens (2016). In columns (3) and (6), the dependent variable is a dummy variable indicating whether the loan observation requires collateral (Secured Loan). Loan purpose and industry-year (Fama-French 30) fixed effects are included in each specification. Standard errors are clustered by firm in all specifications. Variable definitions are in Appendix A. 
Table 6: Bank Debt Reliance Over Time

\begin{tabular}{|c|c|c|c|c|}
\hline & $\begin{array}{c}(1) \\
\text { Bank Reliance }\end{array}$ & $\begin{array}{c}(2) \\
\text { Bank Reliance }\end{array}$ & $\begin{array}{c}\text { (3) } \\
\text { Bank Reliance }\end{array}$ & $\begin{array}{c}(4) \\
\text { Bank Reliance }\end{array}$ \\
\hline \multicolumn{5}{|c|}{ Financial Statement Complexity and Time } \\
\hline FS Length & $\begin{array}{l}-8.968^{* *} \\
(-2.10)\end{array}$ & & $\begin{array}{l}-0.804 \\
(-0.20)\end{array}$ & \\
\hline FS Length $\times$ Time Trend & $\begin{array}{l}2.904^{* * *} \\
(5.51)\end{array}$ & & $\begin{array}{l}0.937^{*} \\
(1.83)\end{array}$ & \\
\hline Bog Index & & $\begin{array}{l}-1.460^{* * *} \\
(-3.24)\end{array}$ & & $\begin{array}{l}-0.949^{*} \\
(-1.76)\end{array}$ \\
\hline Bog Index $\times$ Time Trend & & $\begin{array}{l}0.356^{* * *} \\
(7.58)\end{array}$ & & $\begin{array}{l}0.190^{* * *} \\
(3.63)\end{array}$ \\
\hline Time Trend & $\begin{array}{l}-0.028^{* * *} \\
(-4.95)\end{array}$ & $\begin{array}{l}-0.028^{* * *} \\
(-6.84)\end{array}$ & $\begin{array}{l}-0.010^{*} \\
(-1.90)\end{array}$ & $\begin{array}{l}-0.017^{* * *} \\
(-3.73)\end{array}$ \\
\hline \multicolumn{5}{|c|}{ Firm Fundamentals and Characteristics } \\
\hline Zscore & $\begin{array}{l}-0.011^{* * *} \\
(-21.00)\end{array}$ & $\begin{array}{l}-0.011^{* * *} \\
(-21.21)\end{array}$ & $\begin{array}{l}-0.011^{* * *} \\
(-16.20)\end{array}$ & $\begin{array}{l}-0.011^{* * *} \\
(-16.21)\end{array}$ \\
\hline Firm Size & $\begin{array}{l}-0.013^{* * *} \\
(-8.26)\end{array}$ & $\begin{array}{l}-0.012^{* * *} \\
(-7.84)\end{array}$ & $\begin{array}{l}0.017^{* * *} \\
(4.14)\end{array}$ & $\begin{array}{l}0.018^{* * *} \\
(4.18)\end{array}$ \\
\hline EBITDA & $\begin{array}{l}0.176^{* * *} \\
(12.02)\end{array}$ & $\begin{array}{l}0.181^{* * *} \\
(12.24)\end{array}$ & $\begin{array}{l}0.052^{* * *} \\
(3.04)\end{array}$ & $\begin{array}{l}0.050^{* * *} \\
(2.95)\end{array}$ \\
\hline Book to Market & $\begin{array}{l}-0.012^{* * *} \\
(-5.10)\end{array}$ & $\begin{array}{l}-0.012^{* * *} \\
(-5.07)\end{array}$ & $\begin{array}{l}-0.009^{* * *} \\
(-3.62)\end{array}$ & $\begin{array}{l}-0.009^{* * *} \\
(-3.67)\end{array}$ \\
\hline Tangibility & $\begin{array}{l}0.034^{* * *} \\
(2.85)\end{array}$ & $\begin{array}{l}0.037^{* * *} \\
(3.06)\end{array}$ & $\begin{array}{r}0.028 \\
(1.18)\end{array}$ & $\begin{array}{r}0.026 \\
(1.10)\end{array}$ \\
\hline Loss & $\begin{array}{l}0.010^{* * *} \\
(2.74)\end{array}$ & $\begin{array}{l}0.010^{* * *} \\
(2.75)\end{array}$ & $\begin{array}{l}0.015^{* * *} \\
(5.25)\end{array}$ & $\begin{array}{l}0.015^{* * *} \\
(5.35)\end{array}$ \\
\hline Special Items & $\begin{array}{l}0.009^{*} \\
(1.67)\end{array}$ & $\begin{array}{c}0.008 \\
(1.57)\end{array}$ & $\begin{array}{r}0.004 \\
(1.25)\end{array}$ & $\begin{array}{r}0.004 \\
(1.17)\end{array}$ \\
\hline Returns & $\begin{array}{l}-0.004^{* *} \\
(-2.05)\end{array}$ & $\begin{array}{l}-0.005^{* *} \\
(-2.52)\end{array}$ & $\begin{array}{c}0.000 \\
(0.10)\end{array}$ & $\begin{array}{l}-0.000 \\
(-0.12)\end{array}$ \\
\hline Return Volatility & $\begin{array}{l}0.129^{* * *} \\
(6.46)\end{array}$ & $\begin{array}{l}0.135^{* * *} \\
(6.76)\end{array}$ & $\begin{array}{l}0.094^{* * *} \\
(5.30)\end{array}$ & $\begin{array}{l}0.097^{* * *} \\
(5.49)\end{array}$ \\
\hline Business Segments & $\begin{array}{l}-0.001 \\
(-0.52)\end{array}$ & $\begin{array}{l}-0.002 \\
(-0.87)\end{array}$ & $\begin{array}{r}0.002 \\
(0.61)\end{array}$ & $\begin{array}{c}0.002 \\
(0.68)\end{array}$ \\
\hline Geographic Segments & $\begin{array}{l}-0.014^{* * *} \\
(-5.37)\end{array}$ & $\begin{array}{l}-0.014^{* * *} \\
(-5.34)\end{array}$ & $\begin{array}{l}-0.001 \\
(-0.36)\end{array}$ & $\begin{array}{c}-0.001 \\
(-0.38)\end{array}$ \\
\hline Unrated & $\begin{array}{l}0.011^{*} \\
(1.75)\end{array}$ & $\begin{array}{l}0.010^{*} \\
(1.68)\end{array}$ & $\begin{array}{l}0.019^{* *} \\
(2.15)\end{array}$ & $\begin{array}{l}0.019^{* *} \\
(2.16)\end{array}$ \\
\hline Discretionary Accruals & $\begin{array}{l}-0.011^{* *} \\
(-2.16)\end{array}$ & $\begin{array}{l}-0.011^{* *} \\
(-2.16)\end{array}$ & $\begin{array}{c}0.001 \\
(0.24)\end{array}$ & $\begin{array}{l}0.001 \\
(0.22)\end{array}$ \\
\hline Constant & $\begin{array}{l}0.322^{* * *} \\
(6.65)\end{array}$ & $\begin{array}{l}0.352^{* * *} \\
(8.61)\end{array}$ & $\begin{array}{r}0.023 \\
(0.45)\end{array}$ & $\begin{array}{l}0.093^{*} \\
(1.81)\end{array}$ \\
\hline Industry FEs & Yes & Yes & No & No \\
\hline Firm FEs & No & No & Yes & Yes \\
\hline Adj. $R^{2}$ & 0.18 & 0.18 & 0.66 & 0.66 \\
\hline Observations & 21,775 & 21,775 & 21,775 & 21,775 \\
\hline
\end{tabular}

This table presents the regression results examining whether financial statement complexity influences firm bank reliance, and whether the relation has changed over time. The independent variables of interest in columns (1) and (3) is the borrower's financial statement length (FS Length), and the borrower's financial statement Bog Index (Bog Index) in columns (2) and (4), and the interaction of those variables with the Time Trend count variable. Time Trend corresponds to a value of one for the first fiscal year period in this sample (2001), and increases by an increment of one for each subsequent fiscal year through the end of the sample period (2015). The dependent variable is the total amount of bank debt held by a firm scaled by total assets (Bank Reliance). FS Length and Bog Index are divided by 1000 to facilitate presentation of the coefficients. Columns (1) and (2) include industry (Fama-French 30) fixed effects, and columns (3) and (4) include firm fixed effects. Standard errors are clustered by firm in all specifications. Variable definitions are in Appendix A. 
Table 7: Banking Relationships

\begin{tabular}{|c|c|c|c|c|}
\hline & $\begin{array}{c}\text { (1) } \\
\text { Relationship (\#) }\end{array}$ & $\begin{array}{l}\text { (2) } \\
\text { Relationship (\$) }\end{array}$ & $\begin{array}{c}\text { (3) } \\
\text { Relationship (\#) }\end{array}$ & $\begin{array}{c}\text { (4) } \\
\text { Relationship (\$) }\end{array}$ \\
\hline \multicolumn{5}{|c|}{ Financial Statement Complexity } \\
\hline FS Length & $\begin{array}{l}0.057^{* *} \\
(2.32)\end{array}$ & $\begin{array}{l}0.053^{* *} \\
(2.48)\end{array}$ & & \\
\hline Bog Index & & & $\begin{array}{l}0.006^{* *} \\
(2.05)\end{array}$ & $\begin{array}{l}0.004^{*} \\
(1.82)\end{array}$ \\
\hline \multicolumn{5}{|c|}{ Firm Fundamentals and Characteristics } \\
\hline Zscore & $\begin{array}{r}0.002 \\
(0.37)\end{array}$ & $\begin{array}{c}0.000 \\
(0.09)\end{array}$ & $\begin{array}{r}0.002 \\
(0.30)\end{array}$ & $\begin{array}{c}0.000 \\
(0.01)\end{array}$ \\
\hline Firm Size & $\begin{array}{l}-0.277^{* * *} \\
(-18.31)\end{array}$ & $\begin{array}{l}-0.235^{\text {*** }} \\
(-17.58)\end{array}$ & $\begin{array}{l}-0.272^{* * *} \\
(-18.73)\end{array}$ & $\begin{array}{l}-0.230^{* * *} \\
(-17.79)\end{array}$ \\
\hline EBITDA & $\begin{array}{l}-0.597^{* * *} \\
(-4.55)\end{array}$ & $\begin{array}{l}-0.522^{* * *} \\
(-4.27)\end{array}$ & $\begin{array}{l}-0.596^{* * *} \\
(-4.53)\end{array}$ & $\begin{array}{l}-0.524^{* * *} \\
(-4.28)\end{array}$ \\
\hline Book to Market & $\begin{array}{l}-0.010 \\
(-0.86)\end{array}$ & $\begin{array}{l}-0.006 \\
(-0.61)\end{array}$ & $\begin{array}{l}-0.010 \\
(-0.88)\end{array}$ & $\begin{array}{l}-0.007 \\
(-0.64)\end{array}$ \\
\hline Tangibility & $\begin{array}{c}0.152^{*} \\
(1.81)\end{array}$ & $\begin{array}{c}0.133^{*} \\
(1.76)\end{array}$ & $\begin{array}{c}0.163^{*} \\
(1.93)\end{array}$ & $\begin{array}{c}0.141^{*} \\
(1.86)\end{array}$ \\
\hline Loss & $\begin{array}{l}0.087^{* * *} \\
(3.48)\end{array}$ & $\begin{array}{l}0.085^{* * *} \\
(3.74)\end{array}$ & $\begin{array}{l}0.087^{* * *} \\
(3.49)\end{array}$ & $\begin{array}{l}0.086^{* * *} \\
(3.77)\end{array}$ \\
\hline Special Items & $\begin{array}{l}0.299^{* * *} \\
(3.32)\end{array}$ & $\begin{array}{l}0.291^{* * *} \\
(3.57)\end{array}$ & $\begin{array}{l}0.292^{* * *} \\
(3.24)\end{array}$ & $\begin{array}{l}0.285^{* * *} \\
(3.50)\end{array}$ \\
\hline Returns & $\begin{array}{l}0.031^{* *} \\
(2.24)\end{array}$ & $\begin{array}{l}0.032^{* *} \\
(2.41)\end{array}$ & $\begin{array}{l}0.030^{* *} \\
(2.20)\end{array}$ & $\begin{array}{l}0.031^{* *} \\
(2.39)\end{array}$ \\
\hline Return Volatility & $\begin{array}{l}0.566^{* * *} \\
(3.54)\end{array}$ & $\begin{array}{l}0.534^{* * *} \\
(3.60)\end{array}$ & $\begin{array}{l}0.586^{* * *} \\
(3.67)\end{array}$ & $\begin{array}{l}0.556^{* * *} \\
(3.74)\end{array}$ \\
\hline Business Segments & $\begin{array}{l}-0.017 \\
(-0.82)\end{array}$ & $\begin{array}{l}-0.004 \\
(-0.24)\end{array}$ & $\begin{array}{l}-0.020 \\
(-1.00)\end{array}$ & $\begin{array}{l}-0.007 \\
(-0.39)\end{array}$ \\
\hline Geographic Segments & $\begin{array}{c}0.034 \\
(1.53)\end{array}$ & $\begin{array}{c}0.029 \\
(1.45)\end{array}$ & $\begin{array}{c}0.033 \\
(1.52)\end{array}$ & $\begin{array}{c}0.029 \\
(1.45)\end{array}$ \\
\hline Unrated & $\begin{array}{l}0.127^{* * *} \\
(3.65)\end{array}$ & $\begin{array}{l}0.091^{* * *} \\
(2.80)\end{array}$ & $\begin{array}{l}0.125^{\text {*** }} \\
(3.61)\end{array}$ & $\begin{array}{l}0.090^{* * *} \\
(2.77)\end{array}$ \\
\hline Discretionary Accruals & $\begin{array}{c}0.069^{*} \\
(1.72)\end{array}$ & $\begin{array}{c}0.063^{*} \\
(1.67)\end{array}$ & $\begin{array}{c}0.073^{*} \\
(1.81)\end{array}$ & $\begin{array}{c}0.066^{*} \\
(1.75)\end{array}$ \\
\hline Industry-Year FEs & Yes & Yes & Yes & Yes \\
\hline Adj. $\mathrm{R}^{2}$ & .32 & .29 & .32 & .29 \\
\hline Observations & 14,594 & 14,594 & 14,594 & 14,594 \\
\hline
\end{tabular}

This table presents the regression results examining whether financial statement complexity influences banking relationships. We create borrower-year panels using all existing outstanding loans for each borrower. The independent variables of interest in columns (1) - (2) is the borrower's financial statement length (FS Length), and the borrower's financial statement Bog Index (Bog Index) in columns (3) - (4). We measure bank relationships two ways following Bharath et al. (2011). First, in columns (1) and (3) we calculate Relationship (\#) as the number of loans associated with the lead arranger in the prior five years to the existing outstanding debt, scaled by the total number of loans in the same prior five year period. Second, in columns (2) and (4) we calculate Relationship (\$) as the dollar amount of loans associated with the lead arranger in the prior five years to the existing outstanding debt, scaled by the total dollar amount of loans in the the same prior five year period. For firms with multiple lead arrangers, we use the maximum Relationship (\#) and Relationship (\$) following Bharath et al. (2011) for each firm-year observation. We log both measures for better distributional properties. Each model includes industry-year (Fama-French 30) fixed effects. Standard errors are clustered by firm in all specifications. Variable definitions are in Appendix A. 
Table 8: Disentangling Business and Standards Complexity

\begin{tabular}{|c|c|c|c|c|}
\hline & $\begin{array}{c}(1) \\
\text { Bank Reliance }\end{array}$ & $\begin{array}{c}(2) \\
\text { Bank Reliance }\end{array}$ & $\begin{array}{c}(3) \\
\text { Bank Reliance }\end{array}$ & $\begin{array}{c}(4) \\
\text { Bank Reliance }\end{array}$ \\
\hline \multicolumn{5}{|c|}{ Financial Statement Complexity } \\
\hline Business Complexity & $\begin{array}{l}0.013^{* * *} \\
(4.61)\end{array}$ & & $\begin{array}{l}0.005^{* *} \\
(2.14)\end{array}$ & \\
\hline Bog Index & & $\begin{array}{l}0.002^{* * *} \\
(4.06)\end{array}$ & & $\begin{array}{c}0.001^{*} \\
(1.69)\end{array}$ \\
\hline Standards Complexity & $\begin{array}{r}0.001 \\
(0.49)\end{array}$ & $\begin{array}{l}-0.000 \\
(-0.16)\end{array}$ & $\begin{array}{c}0.000 \\
(0.08)\end{array}$ & $\begin{array}{l}-0.000 \\
(-0.15)\end{array}$ \\
\hline \multicolumn{5}{|c|}{ Firm Fundamentals and Characteristics } \\
\hline Zscore & $\begin{array}{l}-0.012^{* * *} \\
(-19.27)\end{array}$ & $\begin{array}{c}-0.012^{* * *} \\
(-19.37)\end{array}$ & $\begin{array}{c}-0.012^{\text {*** }} \\
(-13.78)\end{array}$ & $\begin{array}{c}-0.012^{\text {*** }} \\
(-13.66)\end{array}$ \\
\hline Firm Size & $\begin{array}{l}-0.015^{* * *} \\
(-8.64)\end{array}$ & $\begin{array}{l}-0.014^{* * *} \\
(-8.37)\end{array}$ & $\begin{array}{l}0.013^{* * *} \\
(2.74)\end{array}$ & $\begin{array}{l}0.013^{* * *} \\
(2.65)\end{array}$ \\
\hline EBITDA & $\begin{array}{l}0.185^{* * *} \\
(11.41)\end{array}$ & $\begin{array}{l}0.187^{* * *} \\
(11.50)\end{array}$ & $\begin{array}{l}0.075^{* * *} \\
(3.72)\end{array}$ & $\begin{array}{l}0.075^{\text {*** }} \\
(3.69)\end{array}$ \\
\hline Book to Market & $\begin{array}{l}-0.011^{\text {*** }} \\
(-4.45)\end{array}$ & $\begin{array}{l}-0.011^{* * *} \\
(-4.44)\end{array}$ & $\begin{array}{l}-0.008^{* *} \\
(-2.49)\end{array}$ & $\begin{array}{l}-0.008^{* *} \\
(-2.50)\end{array}$ \\
\hline Tangibility & $\begin{array}{l}0.038^{* * *} \\
(2.84)\end{array}$ & $\begin{array}{l}0.041^{* * *} \\
(3.09)\end{array}$ & $\begin{array}{c}0.025 \\
(0.87)\end{array}$ & $\begin{array}{c}0.025 \\
(0.88)\end{array}$ \\
\hline Loss & $\begin{array}{l}0.010^{* *} \\
(2.44)\end{array}$ & $\begin{array}{l}0.010^{* *} \\
(2.44)\end{array}$ & $\begin{array}{l}0.015^{* * *} \\
(4.30)\end{array}$ & $\begin{array}{l}0.015^{\text {*** }} \\
(4.28)\end{array}$ \\
\hline Special Items & $\begin{array}{l}0.042^{* * *} \\
(2.89)\end{array}$ & $\begin{array}{l}0.041^{\text {*** }} \\
(2.78)\end{array}$ & $\begin{array}{l}0.022 \\
(1.56)\end{array}$ & $\begin{array}{c}0.022 \\
(1.56)\end{array}$ \\
\hline Returns & $\begin{array}{l}-0.003 \\
(-1.47)\end{array}$ & $\begin{array}{l}-0.004 \\
(-1.64)\end{array}$ & $\begin{array}{r}0.001 \\
(0.66)\end{array}$ & $\begin{array}{r}0.001 \\
(0.62)\end{array}$ \\
\hline Return Volatility & $\begin{array}{l}0.102^{* * *} \\
(4.32)\end{array}$ & $\begin{array}{l}0.107^{* * *} \\
(4.54)\end{array}$ & $\begin{array}{l}0.053^{* *} \\
(2.38)\end{array}$ & $\begin{array}{l}0.053^{* *} \\
(2.36)\end{array}$ \\
\hline Business Segments & $\begin{array}{l}-0.002 \\
(-0.73)\end{array}$ & $\begin{array}{l}-0.003 \\
(-0.99)\end{array}$ & $\begin{array}{r}0.002 \\
(0.48)\end{array}$ & $\begin{array}{r}0.002 \\
(0.45)\end{array}$ \\
\hline Geographic Segments & $\begin{array}{l}-0.013^{* * *} \\
(-4.61)\end{array}$ & $\begin{array}{l}-0.013^{* * *} \\
(-4.63)\end{array}$ & $\begin{array}{l}-0.001 \\
(-0.30)\end{array}$ & $\begin{array}{c}-0.001 \\
(-0.29)\end{array}$ \\
\hline Unrated & $\begin{array}{c}0.004 \\
(0.56)\end{array}$ & $\begin{array}{c}0.003 \\
(0.53)\end{array}$ & $\begin{array}{c}0.012 \\
(1.12)\end{array}$ & $\begin{array}{c}0.012 \\
(1.12)\end{array}$ \\
\hline Discretionary Accruals & $\begin{array}{l}-0.013^{* *} \\
(-2.14)\end{array}$ & $\begin{array}{l}-0.013^{* *} \\
(-2.15)\end{array}$ & $\begin{array}{l}-0.003 \\
(-0.70)\end{array}$ & $\begin{array}{l}-0.004 \\
(-0.75)\end{array}$ \\
\hline Industry-Year FEs & Yes & Yes & No & No \\
\hline Year FEs & No & No & Yes & Yes \\
\hline Firm FEs & No & No & Yes & Yes \\
\hline Adj. $R^{2}$ & 0.19 & 0.19 & 0.67 & 0.67 \\
\hline Observations & 16,369 & 16,369 & 16,369 & 16,369 \\
\hline
\end{tabular}

This table presents the regression results examining whether financial statement complexity arising from intricacy of the applicable accounting standards or the firms' business operations and discussions of performance is associated with bank debt reliance. We disaggregate the 10-K into two components and calculate the respective length of each component - the footnotes to the financial statements (Standards Complexity) and all other narrative disclosure (Business Complexity). In columns (1) and (3), the independent variables of interest are Business Complexity and Standards Complexity. In columns (2) and (4), the independent variables of interest are the 10-K readability (Bog Index) and Standards Complexity. The dependent variable is the total amount of bank debt held by a firm scaled by total assets (Bank Reliance). Columns (1) and (3) include industry-year (Fama-French 30) fixed effects, and columns (2) and (4) include year and firm fixed effects. Standard errors are clustered by firm in all specifications. Variable definitions are in Appendix A. 
Table 9: Non-Bank Debt Reliance

\begin{tabular}{|c|c|c|c|c|}
\hline & $\begin{array}{c}(1) \\
\text { Non-Bank Debt }\end{array}$ & $\begin{array}{c}(2) \\
\text { Non-Bank Debt }\end{array}$ & $\begin{array}{c}(3) \\
\text { Non-Bank Debt }\end{array}$ & $\begin{array}{c}(4) \\
\text { Non-Bank Debt }\end{array}$ \\
\hline \multicolumn{5}{|c|}{ Financial Statement Complexity } \\
\hline FS Length & $\begin{array}{r}0.002 \\
(0.71)\end{array}$ & & $\begin{array}{r}0.003 \\
(1.19)\end{array}$ & \\
\hline Bog Index & & $\begin{array}{r}0.000 \\
(1.22)\end{array}$ & & $\begin{array}{l}0.001^{\text {** }} \\
(2.24)\end{array}$ \\
\hline \multicolumn{5}{|c|}{ Firm Fundamentals and Characteristics } \\
\hline Zscore & $\begin{array}{c}-0.009^{* * *} \\
(-18.59)\end{array}$ & $\begin{array}{c}-0.009^{* * *} \\
(-18.64)\end{array}$ & $\begin{array}{c}-0.009^{* * *} \\
(-10.25)\end{array}$ & $\begin{array}{l}-0.009^{* * *} \\
(-10.21)\end{array}$ \\
\hline Firm Size & $\begin{array}{l}0.018^{* * *} \\
(10.56)\end{array}$ & $\begin{array}{l}0.018^{* * *} \\
(10.84)\end{array}$ & $\begin{array}{l}0.025^{* * *} \\
(5.31)\end{array}$ & $\begin{array}{l}0.025^{* * *} \\
(5.14)\end{array}$ \\
\hline EBITDA & $\begin{array}{l}0.083^{* * *} \\
(5.98)\end{array}$ & $\begin{array}{l}0.084^{* * *} \\
(6.02)\end{array}$ & $\begin{array}{l}-0.022 \\
(-1.12)\end{array}$ & $\begin{array}{l}-0.022 \\
(-1.11)\end{array}$ \\
\hline Book to Market & $\begin{array}{l}-0.037^{* * *} \\
(-13.82)\end{array}$ & $\begin{array}{l}-0.037^{* * *} \\
(-13.85)\end{array}$ & $\begin{array}{l}-0.026^{* * *} \\
(-8.90)\end{array}$ & $\begin{array}{l}-0.027^{* * *} \\
(-8.89)\end{array}$ \\
\hline Tangibility & $\begin{array}{l}0.106^{\text {*** }} \\
(8.31)\end{array}$ & $\begin{array}{l}0.107^{* * *} \\
(8.35)\end{array}$ & $\begin{array}{c}0.039 \\
(1.55)\end{array}$ & $\begin{array}{c}0.040 \\
(1.60)\end{array}$ \\
\hline Loss & $\begin{array}{l}0.037^{* * *} \\
(9.91)\end{array}$ & $\begin{array}{l}0.037^{* * *} \\
(10.00)\end{array}$ & $\begin{array}{l}0.017^{* * *} \\
(5.79)\end{array}$ & $\begin{array}{l}0.017^{* * *} \\
(5.68)\end{array}$ \\
\hline Special Items & $\begin{array}{l}-0.003 \\
(-0.32)\end{array}$ & $\begin{array}{l}-0.003 \\
(-0.33)\end{array}$ & $\begin{array}{l}-0.011^{* *} \\
(-2.47)\end{array}$ & $\begin{array}{l}-0.011^{* *} \\
(-2.52)\end{array}$ \\
\hline Returns & $\begin{array}{l}-0.007^{* * *} \\
(-3.36)\end{array}$ & $\begin{array}{l}-0.007^{* * *} \\
(-3.40)\end{array}$ & $\begin{array}{l}-0.006^{* * *} \\
(-2.95)\end{array}$ & $\begin{array}{l}-0.006^{* * *} \\
(-2.94)\end{array}$ \\
\hline Return Volatility & $\begin{array}{l}0.159^{* * *} \\
(7.25)\end{array}$ & $\begin{array}{l}0.159^{* * *} \\
(7.32)\end{array}$ & $\begin{array}{l}0.125^{* * *} \\
(5.81)\end{array}$ & $\begin{array}{l}0.123^{* * *} \\
(5.74)\end{array}$ \\
\hline Business Segments & $\begin{array}{l}-0.000 \\
(-0.09)\end{array}$ & $\begin{array}{l}-0.001 \\
(-0.19)\end{array}$ & $\begin{array}{l}-0.005 \\
(-1.22)\end{array}$ & $\begin{array}{l}-0.005 \\
(-1.32)\end{array}$ \\
\hline Geographic Segments & $\begin{array}{l}-0.009^{* * *} \\
(-3.75)\end{array}$ & $\begin{array}{l}-0.009^{* * *} \\
(-3.74)\end{array}$ & $\begin{array}{r}0.001 \\
(0.17)\end{array}$ & $\begin{array}{r}0.001 \\
(0.18)\end{array}$ \\
\hline Unrated & $\begin{array}{c}-0.100^{* * *} \\
(-15.73)\end{array}$ & $\begin{array}{l}-0.100^{* * *} \\
(-15.76)\end{array}$ & $\begin{array}{l}-0.086^{* * *} \\
(-8.72)\end{array}$ & $\begin{array}{l}-0.086^{* * *} \\
(-8.73)\end{array}$ \\
\hline Discretionary Accruals & $\begin{array}{r}0.001 \\
(0.19) \\
\end{array}$ & $\begin{array}{r}0.001 \\
(0.19) \\
\end{array}$ & $\begin{array}{r}-0.001 \\
(-0.23) \\
\end{array}$ & $\begin{array}{l}-0.001 \\
(-0.25) \\
\end{array}$ \\
\hline Industry-Year FEs & Yes & Yes & No & No \\
\hline Year FEs & No & No & Yes & Yes \\
\hline Firm FEs & No & No & Yes & Yes \\
\hline Adj. $R^{2}$ & 0.41 & 0.41 & 0.72 & 0.72 \\
\hline Observations & 21,775 & 21,775 & 21,775 & 21,775 \\
\hline
\end{tabular}

This table presents the regression results examining whether financial statement complexity influences firm non-bank debt reliance. The independent variable of interest for columns (1) and (3) is the borrower's financial statement length (FS Length), and in columns (2) and (4) borrower's financial statement Bog Index. The dependent variable is the total amount of non-bank debt held by a firm scaled by total assets (Non-Bank Debt). Columns (1) and (2) include industryyear (Fama-French 30) fixed effects, and columns (3) and (4) include year and firm fixed effects. Standard errors are clustered by firm in all specifications. Variable definitions are in Appendix A. 


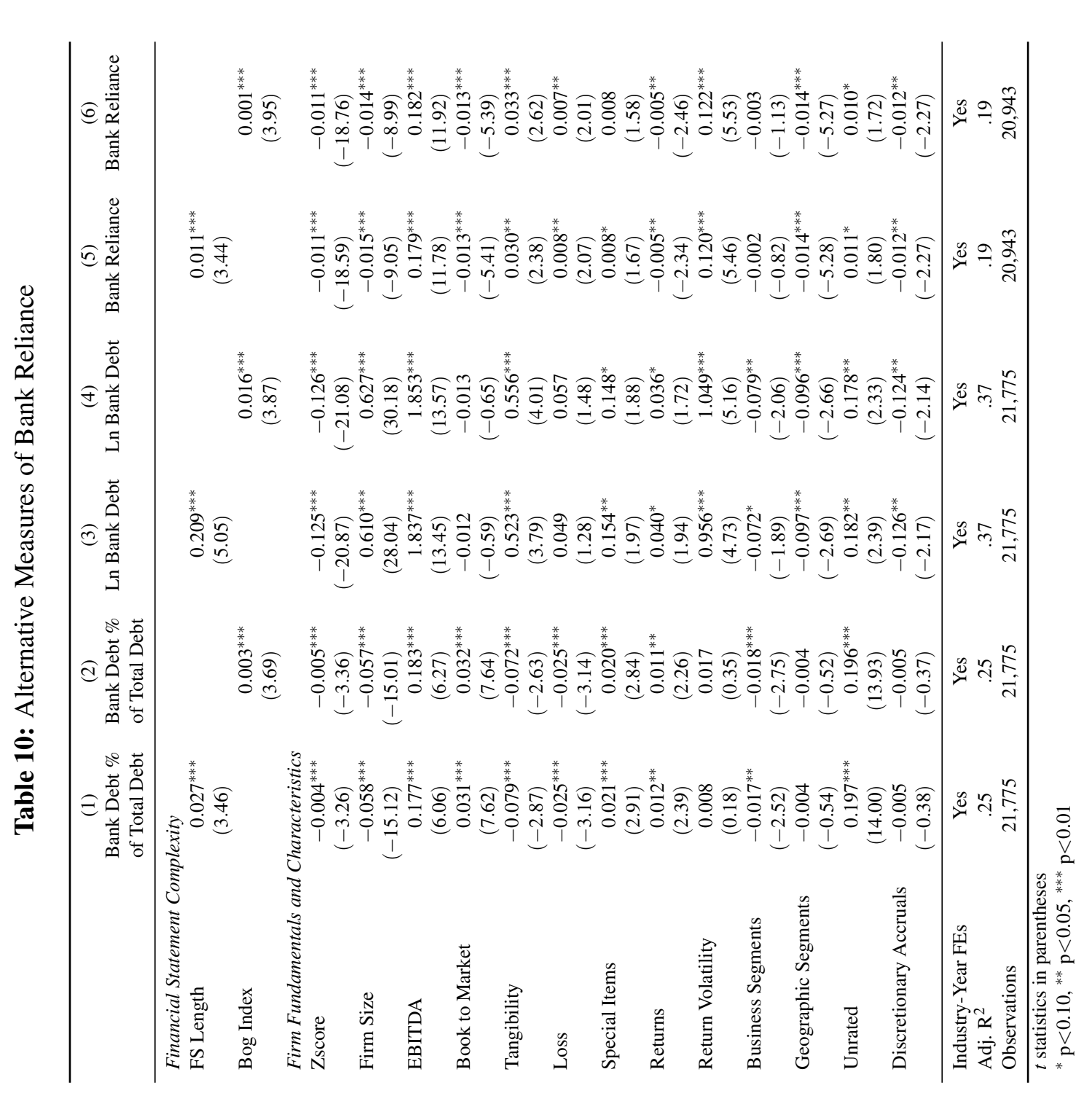

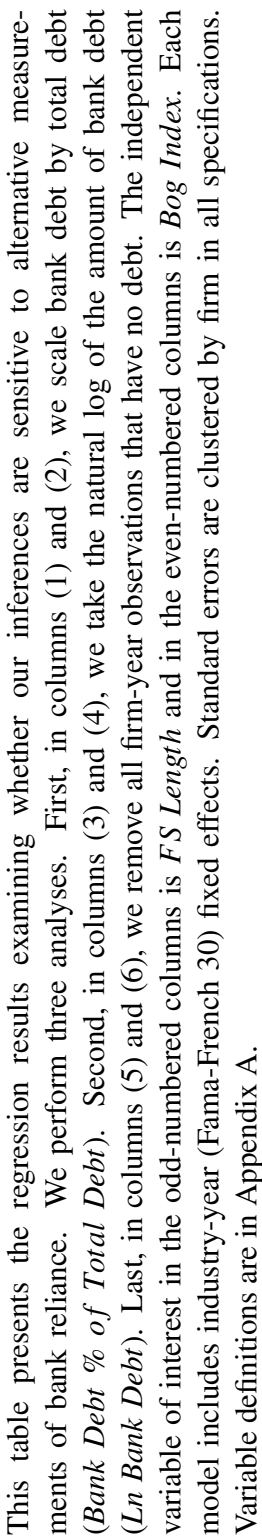




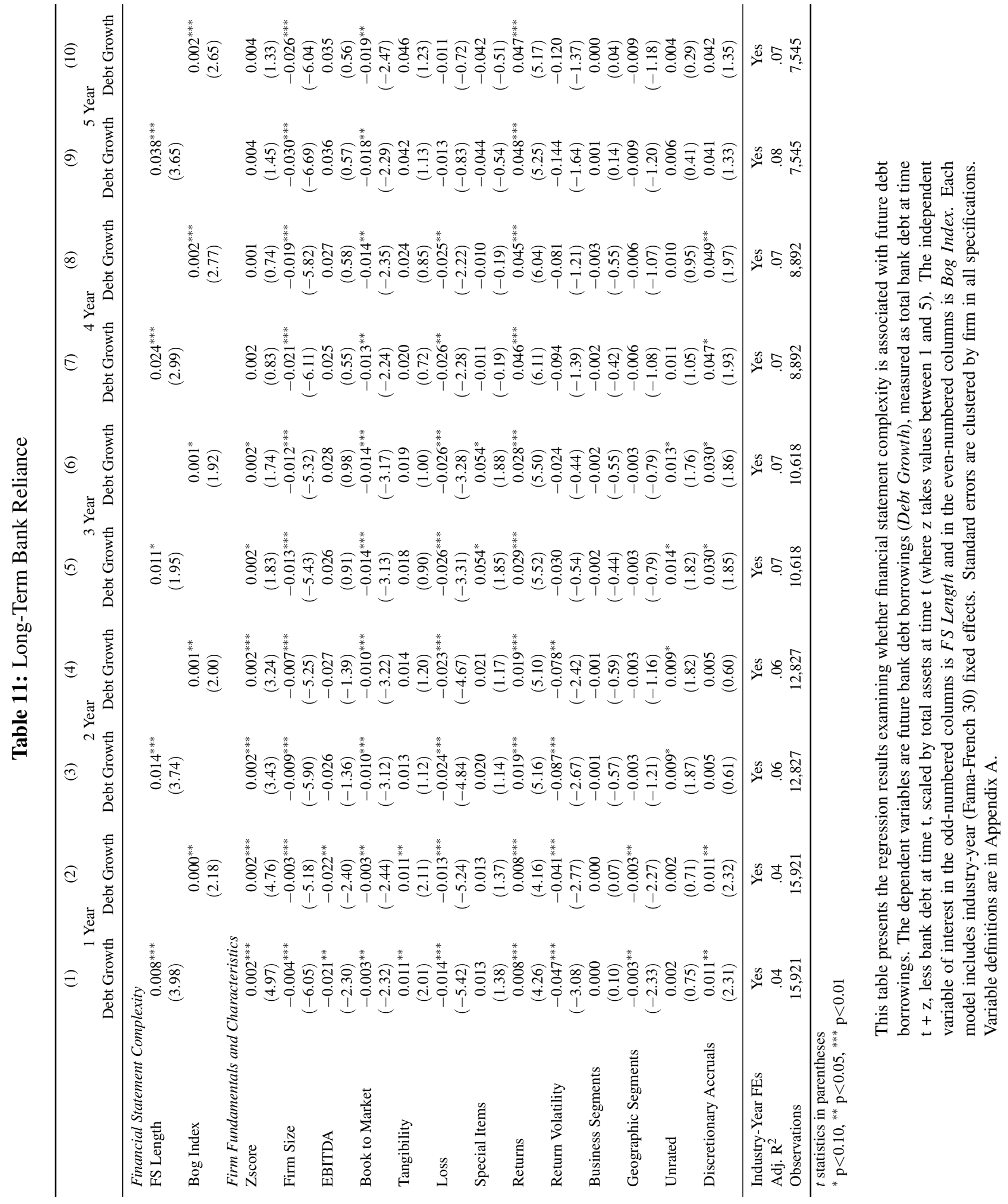




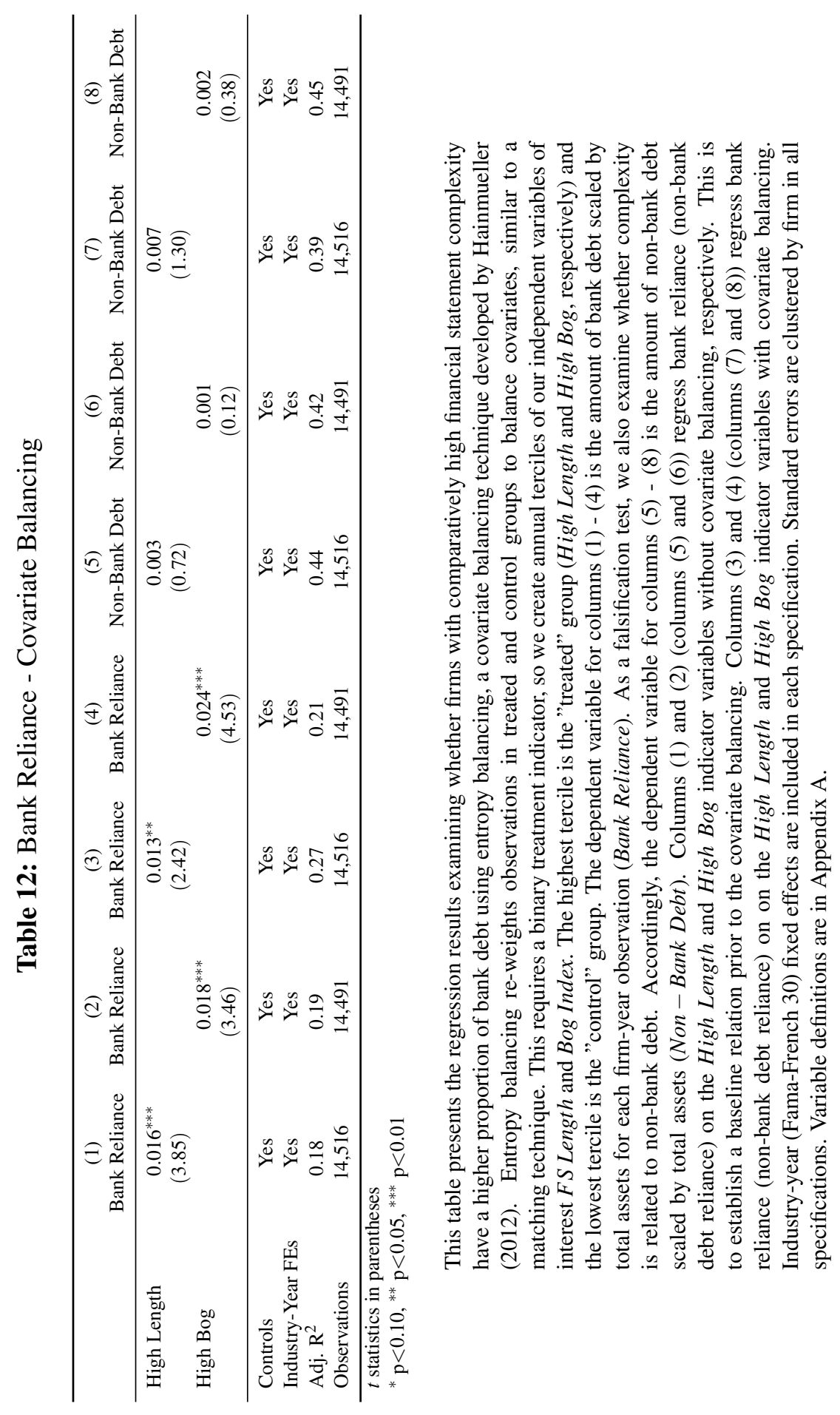




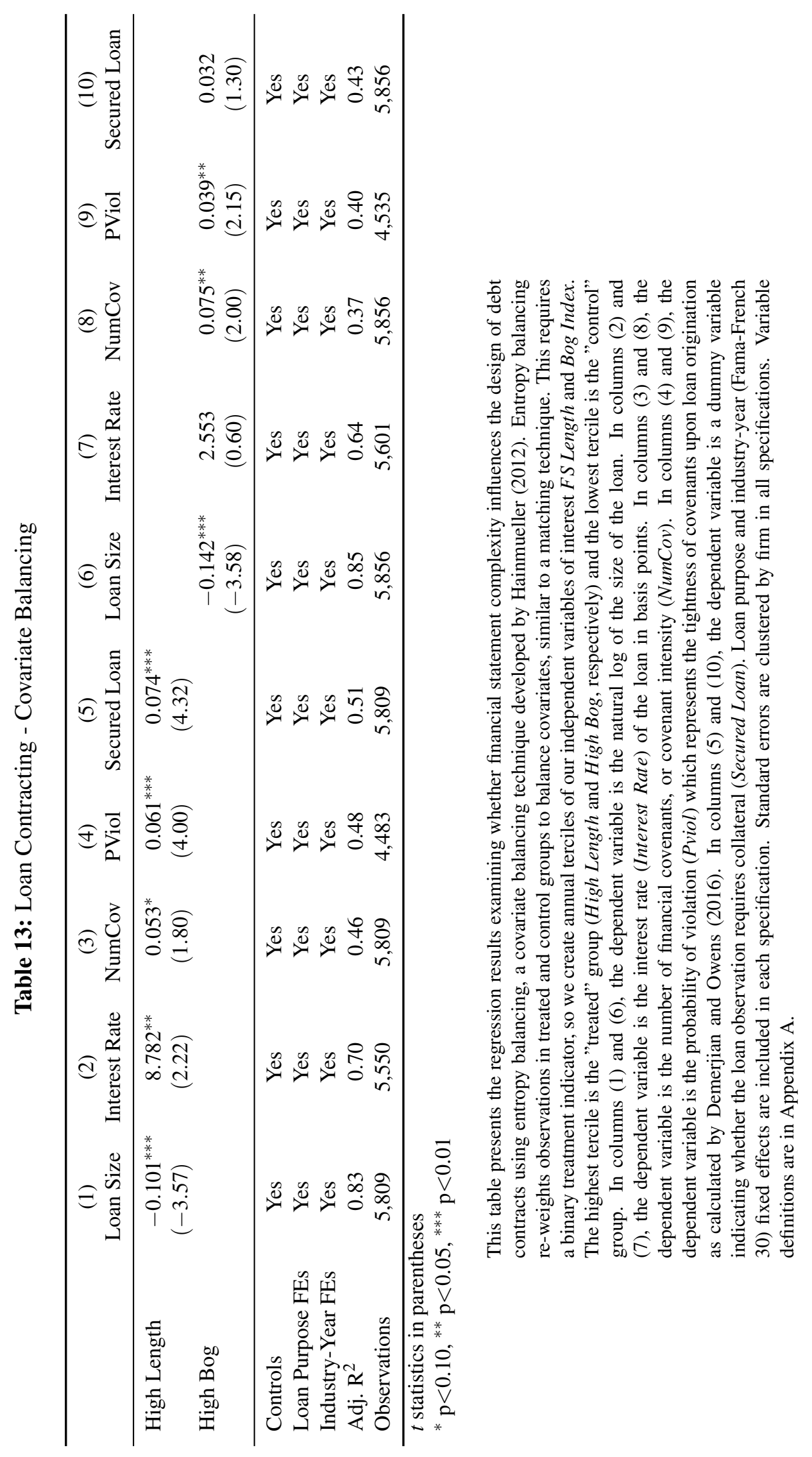

